\title{
Seasons in the Woods---Exploring Whether Seminar Attendance Is Influenced When Landowners Are Involved in Topic Selection
}

Agnes Kedmenecz

Follow this and additional works at: https://researchrepository.wvu.edu/etd

\footnotetext{
Recommended Citation

Kedmenecz, Agnes, "Seasons in the Woods---Exploring Whether Seminar Attendance Is Influenced When Landowners Are Involved in Topic Selection" (2017). Graduate Theses, Dissertations, and Problem Reports. 5954.

https://researchrepository.wvu.edu/etd/5954

This Thesis is protected by copyright and/or related rights. It has been brought to you by the The Research Repository @ WVU with permission from the rights-holder(s). You are free to use this Thesis in any way that is permitted by the copyright and related rights legislation that applies to your use. For other uses you must obtain permission from the rights-holder(s) directly, unless additional rights are indicated by a Creative Commons license in the record and/ or on the work itself. This Thesis has been accepted for inclusion in WVU Graduate Theses, Dissertations, and Problem Reports collection by an authorized administrator of The Research Repository @ WVU. For more information, please contact researchrepository@mail.wvu.edu.
} 


\title{
Seasons in the Woods-Exploring whether seminar attendance is influenced when landowners are involved in topic selection
}

\author{
Agnes Kedmenecz \\ A thesis submitted to the Davis College of Agriculture, Natural Resources and Design \\ At West Virginia University \\ In partial fulfillment of the requirements for the degree of \\ Master of Science in Forestry \\ David McGill, Ph.D., Chair \\ David Smaldone, Ph.D. \\ Emily Perdue, Ph.D.
}

Division of Forestry and Natural Resources

Morgantown, West Virginia

2017

Keywords: Topic selection, direct mail, woodland owners

Copyright 2017 Agnes Kedmenecz 


\begin{abstract}
Seasons in the Woods-Exploring whether seminar attendance is influenced when landowners are involved in topic selection

\section{Agnes Kedmenecz}

Private woodland owners play a key role in maintaining and improving environmental amenities for local and downstream communities. To support these owners in making informed land-use decisions, extension professionals often rely on needs assessments to develop well attended educational outreach programs that reflect their ever changing educational needs. Recent work, however, has indicated a low correlation between woodland owners' expressed educational needs and seminar attendance.

Seasons in the Woods is a three-part woodland focused education series used to explore whether landowners would be more likely to express interest, register, and attend forestry education seminars if they were given the chance to select the seminar topic. Outreach to 3600 woodland owners was conducted exclusively by direct mail. To control for variation in responses due to general public interest in educational seminars and to facilitate the monitoring of workshop participants. Seminars were delivered approximately four months apart.

Our study showed a low, non-significant correlation between expressed interest in topics and actual attendance. The treatment group whom was able to select the topic showed a greater attendance rate $(1.11 \%)$ than those who only received a postcard invitation $(0.69 \%)$, but a slightly smaller attendance rate than the group who were just invited to the 3-part series (1.21\%). The surprising finding was that almost half (42\%) of the attendees to seminar one were New Comers (NC). The New Comers were participants who attended the first seminar, even though they received zero direct mail contact or invitations from this study. Once the NC's were assigned to the corresponding treatment group of the person that they attended with, the numbers of attendees among treatment groups changed so much so that there was a significant association between treatment and seminar attendance. 


\section{Acknowledgements}

I would like to thank my advisor Dr. Dave McGill for his guidance and encouragement. Thank you.

The thesis committee members Dr. Dave Smaldone and Dr. Emily Perdue for their expertise. Thank you.

Ida Hosalova for statistical analysis assistance, the chocolate and support.

Thank you.

I would like to thank the many wonderful woodland owners of West Virginia that I was fortunate to meet.

Thank you.

A big thank you to my Mom. Words cannot describe how thankful I am for your support. Thank you.

To all of my friends back in Canada who have been my cheerleaders and supporters, thank you for your love and encouragement. And to the friends I have made in West Virginia.

Thank you.

Finally, I would like to thank God for this great opportunity and lessons learned. Thank you. 


\section{TABLE OF CONTENTS}

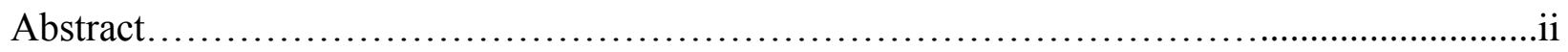

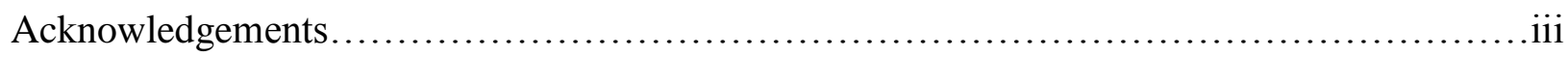

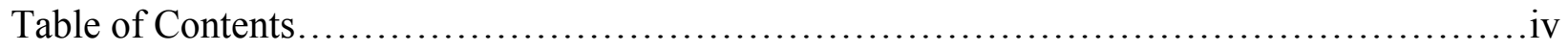

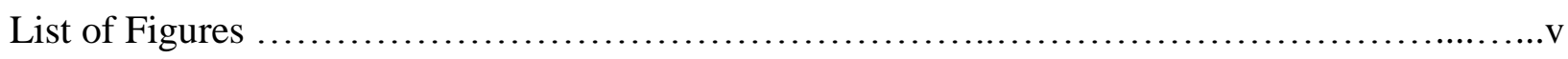

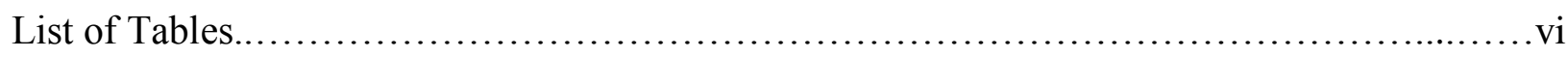

Chapter 1: Introduction.........................................................

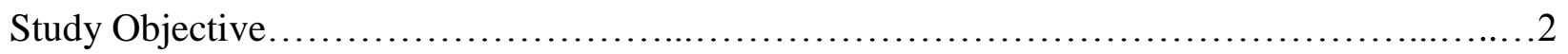

Chapter 2: Literature Review...................................................4

The Woodland Owner .............................................................

Direct Mailing ................................................................... 6

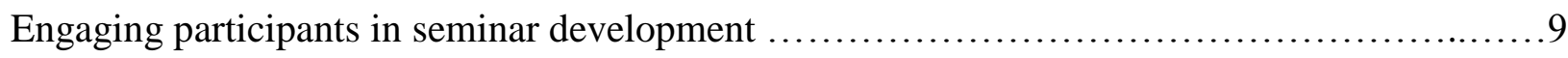

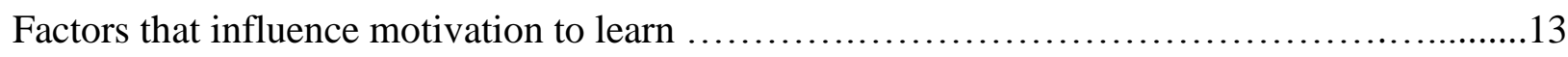

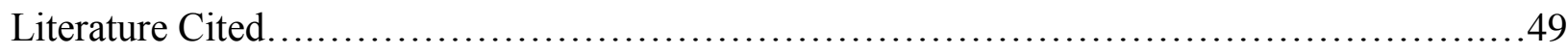

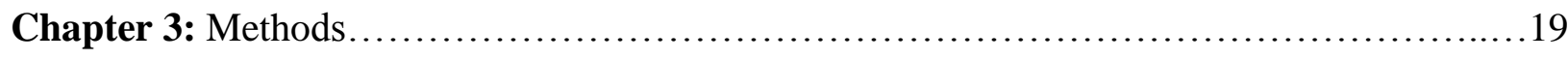

Chapter 4: Results......................................................... 32

Chapter 5: Discussion..................................................... 43

Chapter 6: Conclusions......................................................46 


\section{LIST OF FIGURES}

Figure $\quad$ Page

1. Introductory letter for the Topic Participant group $\ldots \ldots \ldots \ldots \ldots \ldots \ldots \ldots \ldots \ldots .21$

2. Topic selection with response postcard for the Topic Participant

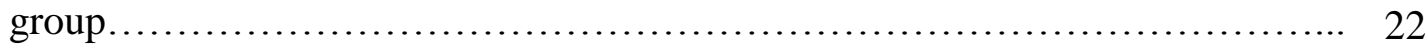

3. Seminar one reminder postcard for the Topic Participant group................ 22

4. Introductory letter for the Pre-notification group........................ 23

5. Response postcard for the Pre-notification group......................... 24

6 Seminar reminder postcard for the Pre-notification group...................... 24

7. Seminar Postcard invitation for IO group............................. 25

8. Illustrated delivery method of the first seminar for the three treatment groups.... 26

9. Example of postcard invitation for seminar two taken from Hampshire

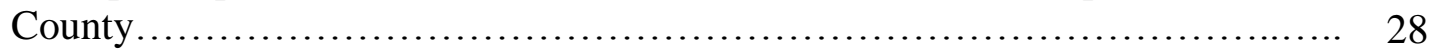

10. Example of postcard invitation for seminar three taken from Greenbrier

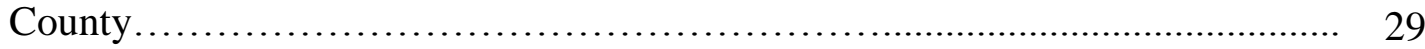

11. Pie chart illustrating number and percent of participants attending the first seminar...

Comparison of attendance prior to New Comers being assigned with their linked treatment group $(n=23)$.

Association between attending seminar one and attending seminar two, of those that expressed interest at onset of seminar series $(n=41)$.

14. Association between attending seminar one and attending seminar three, of those that expressed interest at onset of seminar series $(n=41)$.

15. Association between attending seminar two and attending seminar three, of those that expressed interest at onset of seminar series $(n=41)$. 


\section{LIST OF TABLES}

Table

Page

1. Treatment Groups with type of direct-mail contact each group received...............................................................

2. Logistic regression analysis of topic selection on response, interest, registration, and attendance of first seminar.

3. Logistic regression analysis of treatment group on registration and attendance of first seminar.

4. Number of seminar attendees by group. NC represents newcomers along with associated seminar number.

5. Total unique participants who attended only one seminar and the unique participants who attended two or more seminars. This is per treatment and the new comers

6. Logistic regression analysis of treatment group on likelihood of attending a seminar over the three consecutive seminars 


\section{Chapter 1: Introduction}

Private woodland owners play a key role in maintaining and improving environmental services to local and downstream communities. A woodland owner's relationship to and knowledge of the land can support a sustainable, healthy forest, especially in regards to the flow of ecosystem services, timber and non-timber forest products (Butler \& Leatherberry, 2004). Alone these landowners have a small impact on these services, however, collectively their impact is large (Kuhns et al. 1998)

The goal of natural resource educators and extension professionals is to provide current and relevant information to landowners so they can make informed decisions regarding forest management. As new policy issues arise, timber markets fluctuate, and land is transferred from one landowner to the next, extension education must adapt to the new issues faced in these changing conditions. Forestry professionals rely on needs assessments for developing educational outreach programs that address these ever-changing interests of woodland owners (Butler, 2008).

Needs assessments allow people to provide input as to their perception of what information or technologies they might need to make their landownership more productive, safe, or environmentally sustainable. For the landowner, completing an educational needs assessment is an opportunity enabling them to make a choice of programing in which they might participate. Effective choices enable people to feel in control by contributing to the education process, it gives them a sense of purpose and a sense of competence (Perks, 2012). Providing people with choice also acknowledges their perspectives and feelings thus enhancing intrinsic motivation and interest (Deci, 1992). Perks (2012) found that simply providing learners with options, such as a short list of topics, works well to motivate students as this gives them a sense of control. It has been found that those that are free to select their own activities then go slightly beyond their existing capabilities (Renninger, 1992). By enabling landowners to select their own topics it can be thought that they may use the learning experience to go beyond their existing capabilities towards finding the willingness to enhance their enjoyment and the potential of their woodland property. 
Offering woodland landowners the most popular topic does not always predict how well attended a seminar will be. The recent work of Zobrist \& Rozance (2015) has indicated a low correlation between expressed woodland owner educational needs and workshop attendance. In over six years of offering workshops based on highly ranked topics such as forest health, estate planning and wildlife, they found attendance was low. However, when workshops based on lower-ranked topics such as non-timber forest products and safe tool use were offered they found that workshops were well attended. Malmsheimer \& Germain (2002) speculated that low attendance may be due to providing education seminars too long after the landowner needs assessment was completed.

There are many ways to reach out and promote educational events to woodland owners such as radio, newspaper, television advertising, social media, community newsletters, word of mouth, billboards and of course direct mail. These outreach methods are widely used by extension professionals as landowners have broad preferences for the ways they obtain information regarding technology, policy and financial information related to their property (Riesenburg, 1985). Direct mail is one of the more traditional methods for advertising and outreach efforts. Hughes et al. (2005) found that direct mail can be very effective when mailed out to a specific group. Their 2005 study of effective outreach methods found that $60 \%$ of those who attended their woodland focused workshops learned about the event via a direct letter mailed to them, compared to other means of outreach used such as radio, church, newspaper, flyer and personal contact. Importantly, in using direct mail even if the intended invitee does not attend the advertised event, they have become aware of the program (Londo et al. 2008).

In an effort to further explore outreach methods, we developed a three-part woodland educational seminar series to study how attendance is associated with learners are given the' opportunity to select topics. The goal was to increase understanding of woodland owner needs and preferences for education related to woodland conservation. Specifically, the research questions being asked are:

1. How does topic selection affect the likelihood that landowners will attend the first of the three seminars? 
2. How does topic selection affect the likelihood that landowners will attend seminars throughout a three-seminar series? 


\section{Chapter 2: Literature Review}

This project aimed to explore how attendance is affected when woodland owners are involved in selecting educational topics via direct mail response. To support this research effort, this review of literature examined the basic nature of private nonindustrial woodland owners, the use of direct mail as a common form of advertising, methods for engaging learners in seminar development and factors that influence the motivation to learn.

\section{The Woodland landowner}

Nonindustrial private forests make up the large majority of land ownership in the eastern United States (Butler \& Leatherberry, 2004). Butler et al. (2006, p. 3) defines the nonindustrial private forest owner as "families and individuals who own forest land and corporations and other private groups that own forest land, but do not own and operate a primary wood-processing facility".

Individually, woodland landowners have a small impact on a forest system, however, collectively their impact is large (Kuhns et al. 1998). This large ownership group vary in age, how they use their forest land (homestead or recreation), ownership type (single, multi owner, absentee) and land management objective (managing for wildlife, agro forestry, conservation). Many studies show gradual increasing division, or parcelization, of woodlands into gradually smaller tracts (McCuen et al. 2013). Therefore, the number of forest landowners is increasing and so are management priorities (Salmon et al. 2006). It is these growing numbers that make this group uniquely challenging to reach (Kuhns et al. 1998). Forest economists have indicated the importance of understanding and incorporating the varied land objectives into forestry outreach (Salmon et al. 2006). To understand the needs of woodland owner many studies have been done to categorize them in to groups based on their land use objectives. It is suggested that by categorizing woodland owners, extension agents, foresters and those reaching out to woodland owners will have a better understanding of their needs and interests and thus be more successful in any outreach efforts. Khanal et al. (2017) completed a direct mail survey of 5000 woodland owners in an effort to segment them based on their forest management behaviors and their climate change beliefs and their understanding of carbon sequestration. The typologies 
Khanal et al. (2017), formulated were Amenity, Multi-objective and Timber woodland owners. In a similar study conducted by Salmon et al. (2006), Utah woodland owners were segmented into three categories--Amenity-focused, Multiple-benefits and Passive landowners. In an attempt to better understand and reach woodland owners, Butler et al. (2007) performed a number of multivariate and hierarchical cluster analyses using the National Woodland owners' survey. This analysis then created four clusters of woodland owners based on their land-related goals and attitudes. The groups were 1) Woodland Retreat owners, who live on their woodlands and own a small parcel 2) Working the Land owners, who are interested in a variety of forest benefits including financial, recreation and scenic 3) Supplemental Income owners, who have most likely harvested trees, have the land green certified, have a conservation easement or have participated in a cost-share program 4) Ready to Sell owners who are likely to sell in five years. These studies found that categorizing woodland owners can be challenging because woodland owners change over time as do their land use objectives.

To add to the complexity of understanding woodland ownership and ownership objectives, not all woodland landowners are well educated on matters related to land management. Kuhns et al. (1998) found that woodland owners tend to lack forestry expertise. This lack of expertise was identified West Virginia by the 2013 National Woodland Owner Survey, 2013, as only 5\% of West Virginia woodland owners have attended a workshop related to forestry in the last five years. As outreach educators in West Virginia, this become relevant as West Virginia (WV) is the third most forested state with $78 \%$ of the land being forested and of this, family forest owners account for $60 \%$ of the ownership (Widmann et al., 2008). Woodland ownership in West Virginia is mostly joint ownership (60\%), individual ownership is $29 \%$ and family partnerships are $11 \%$. Most (60\%) of woodland owners live near their primary residence while $17 \%$ consider their woodlands a vacation home. Eighteen percent of the primary owners of WV woodlands are female while secondary ownership is $82 \%$ female. The top reason WV woodland owners own their land is to enjoy the beauty and scenery and the lowest reason is nontimber forest product. West Virginia offers woodland owner financial incentives and tax breaks to assist them with managing the woods. The majority of owners (87\%) were not familiar with property tax programs offered by state nor aware of the cost share programs (77\%) available. Direct mail is one way to inform woodland owners of programs related to their land including educational programs. 


\section{Direct Mailing}

Direct mail is a common and traditional method for advertising for extension programming. Direct mail can be defined as postal mail that is unsolicited and the sender's intent is to sell a product or service to the recipient (Morimoto \& Chang, 2006). It is also defined by the direct marketing experts at Ballantine (2015) as marketing using the US Postal Service.

When direct mails is picked up from the mailbox it is important to understand how the receiver may react to the mail. This can guide how the sender designs the mail. A study conducted by Evans et al. 2001 in the United Kingdom, explored how consumers react to all forms of direct mail. Consumer's key concerns were privacy, relevance and control. Privacy emerged as a concern to some of the study subjects as it represents an invasion of their physical privacy (direct marketing intruding their home) and a worry regarding how the information about consumers became available. Relevance (is the information/service/product applicable to the indented consumer) was found to have four variations; interest, timeliness, repetition and information processing effect. To improve relevance there must be improvements in narrowing down the target group. Control underpins relevance and privacy as it refers to what, when and how things get sent. Consumers react with a mix of contradictions to direct marketing as they increasingly buy things via phone or mail yet are cynical about marketer's intentions and approaches (Evans et al. 2001).

Morimoto \& Chang (2006) studied how the receiver of direct mail responses to multiple mailings. Morimoto \& Chang (2006) assessed 119 individuals attitude towards unsolicited commercial e-mails and postal direct mail. They found three factors, under the framework of psychological reactance, that influence a consumer's attitude regarding direct marketing. These factors are 1) perceived advertising intrusiveness, 2) perceived loss of control, and 3) irritation caused by the repetition. Perceived advertising intrusiveness can be defined as the degree at which unwanted mail interferes with one's cognitive process as well as interference with materials that includes offensive material. It has been found that the electronic form of direct mail (e-mail spam) is perceived as more intrusive than postal direct mail. The direct mail recipient's perceived sense of loss of control is manifested in behaving in the opposite manner of what was intended by the mailer. The receiver may begin to feel as though they have lost the 
freedom to engage in some behaviors and may feel as they have lost control of their own behaviors. Irritation, the third influential factor towards consumer's attitudes, is defined as the negative impatience and displeasing feeling caused by direct marketing communication (Morimoto \& Chang, 2006).

Digital mail and marketing are common place in today's world, however, direct mail continues to play an efficient, important role in getting information out an intended audience. The Ballantine Corporation has implemented direct marketing initiatives for businesses in the U.S. since 1966. They have found that a business or a corporation that use letters, postcards brochures or catalogs to target individuals are at greater likelihood to have the recipients utilize the mailed offer. Postcards are a very effective method of direct mail as the recipients address appears on the front while the offer is on the back and there is no need to open it (Ballantine, 2015). The best response rate are from postcards with large print and the receiver is asked to call or visit a website. It was also found that format quickly arouses interest in the offer and entices the consumer to take further actions to either visit the website or call the phone number on the postcard. The Ballantine Corporation also suggest that targeting any mailing to a specific audience/consumer base can be the key to maximizing marketing dollars and if executed properly can have great returns and high response rates. Direct mail marketing was found to have a response rate of $4.4 \%$ in 2012 while electronic mail response rate was $0.12 \%$. On average, households that earn $\$ 150,000$ or more per year responded to 2.2 pieces of direct mail a week (Ballantine, 2015). Also, 65\% of consumers across all ages have bought something from direct mail. For best results, an offer must be solution based, as opposed to strictly products and services must be given to the consumer.

Ballantine suggests utilizing various methods at differing time intervals to reach the target audience. A study completed by Hock et al. 2012 compared invitation phone calls with invitation letters to encourage stakeholders to attend a civic meeting. Phone calling was found to be as those who received a phone call were twice as likely to attend the city meeting when compared with those who received the invitation letter. (Hock et al. 2012).

From farmer, to woodland owner to the broader community, direct mail can be a successful tool to invite landowner to educational events. Findings in a study focused on attendance quality and future land management workshop for to a family farm owners, showed 
that direct mail was the most effective way to reach landowners (Jones et al. 2008). To encourage farm owners to attend a natural resources enterprise workshop, various modes of advertising were used: direct mail, newspaper, partner organizations, radio, posting in the extension office and other means (such as word of mouth, farm store). Of the 146 participants who attended the workshop, 39 participants (27\%) heard of the workshop through a direct mailed brochure related to the workshop (Jones et al. 2008). Hughes et al. (2005) also found that mailing had a positive effect on workshop attendance. In an attempt to reach underserved woodland landowners regarding a woodland focused workshop, Hughes et al. (2005), used a variety of methods to reach them. These methods included radio, church, newspaper, flyer/brochure, personal contact and direct mail (letter). It was found that although direct mail was expensive, it was the primary way participants learned about the workshop. Sixty percent of forest landowner attendees learned about the workshop via letter. They found "workshop attendance was directly related to the number of landowner letters mailed" (Hughes et al. 2005). This was also found through Lockard et al. (2010) outreach study inviting the broader community to a Family and Consumer Science educational program via direct mail. Lockard et al. (2010) examined the best advertising methods to utilize with a dwindling extension budget. They found that modestly priced advertising is an effective way to extend program outreach. This study compared enrollment numbers of the same Family and Consumer Science education programs offered twice in a 12-month period. One of the programs was promoted using free advertising and the second used paid advertising. The free advertising was word of mouth, flyers, brochures, community bulletin boards and the mailed out and digital Extension newsletters. The paid advertising included newspaper, billboards and radio but did depend on community resources. The enrollment number for the program that was promoted using the free outlets had an average enrolment of 4.5 people while the paid advertising had an average enrollment of 31.8 people (Lockard et al. 2010). Londo et al. (2008) suggest designing the direct mailing campaign to encourage landowners to access a website relevant to item/service being offered as well as announcing multiple events within one mailing. They also found an additional benefit to direct mailing is that even if the recipient did not attend, is the awareness of forestry extension programs and reaching a new clientele (Londo et al. 2008). By being aware of this benefit, an outreach educator may consider multiple mailings. 


\section{Advertising repetition}

Direct mail repetition such as a weekly mailed advertisement was found either to bore the receiver or increase trust in the product. When using repeated exposure to advertise messages one can consider the Berlynes two-factor theory (Anand \& Sternthal, 1990). This theory is based on two factors that can affect the receiver of repeated exposures to an advertising message. These factors are positive habituation and tedium. The positive habituation factor refers to the reduced uncertainty and increase trust of what once was a new product. The tedium factor refers to repetition causing boredom and satiation. This theory asserts that the initial surge of repetition will have a greater impact on habituation yet as repetition increases the tedium effect also increases (Anand \& Sternthal, 1990).

\section{Tax roll data}

Methods to acquire addresses for a woodland owner direct mail campaign include: services such as Stamps.com, previous mailing lists or the county tax roll. Tax roll data can be acquired by the county tax department. This data contains the address of all property owners in the county. Measells et al. (2006) recommends creating a woodland owner database based on tax roll data. Londo et al. (2008) found that to best apply tax roll addresses to a mailing list, it needs to be corrected. These corrections include the removal of duplicates and the correction of misspelt words. Some counties may have updated the county database to reflect the changes in county wide 9-1-1 emergency address, therefore, this list may require some sorting to ensure that the addresses are compatible with the U.S.A. Postal Service mailing standards. Londo et al. (2008) noted three factors to be successful with direct mailing: 1) The market must be correctly identified, 2) An effective message must be delivered and 3) Apply a mailing list that is screened to reflect the audience to be targeted.

\section{Engaging participants in seminar development}

Caffarella et al. (2013) suggest that actively involving participants before during and after a program can build learner support. Involving them before the program can include helping with the planning of the program. Participant feedback and suggestions via evaluation before, during and after the program, will build participant support for education programs (Caffarella et al. 2013). 


\section{Choice}

To foster greater levels of interest and engagement many teachers use choice. Perks (2012) found that effective choice enables people to feel in control, it gives them a sense of purpose and a sense of competence. Providing learners with a short list of topics and an option to create their own topic has been found to work well to motivate students as this gives them a sense of control (Perks, 2012). When learners are provided choice, Smathers et al. (2012) found they are able to take ownership of their learning and will thus feel empowered. Giving choice makes them feel a part of the learning process (Smathers et al. 2012).

Not all choices can have a positive effect on motivation and achievement. Iyengar \& Lepper's (2000) research investigating effective amounts of choice, showed that there can be too much choice. Excessive choice can create "choice paralysis". Self-blame, excessively high expectation, even anxiety and regret can occur if their choice doesn't work out. When the number of choices is small the cost to the individual is less as their personal costs grow with increased choice (Iyengar \& Lepper, 2000). This work is also supported by Schwartz, (2006) as he found there can be too much choice. Excessive choice can create "choice paralysis" and lower the chooser's satisfaction with their decision (Schwartz, 2006). Offering choice can make educators vulnerable as they are taking some level of risk (Bradley et al. 2012). The group may choose a subject that the educator is not fully prepared for. However, by offering choice, the learning and teaching becomes a reciprocal process.

\section{Word of Mouth}

By engaging participants in seminar development, a sort of working relationship is forming, Bess \& Traub, (2013) found this relationship building contributes to a successful education program. When participants have a positive experience in a program it leads to positive word of mouth leading to higher attendance for upcoming programs. The four reasons they had successful attendance to their Matter of Balance education program at University of Missouri extension. These four reasons are participants are 1) familiar with and felt comfortable with the instructors, 2) using varied teaching techniques, 3) the social nature of the group and developing friendships and lastly, 4) participants were inspired to take action (in this case to improve their health). 
Word of mouth (one person who has attended a seminar in the past tells others about their experience) is one way to let others become aware of educational events. When a program is successful many participants will spread the word about how good and useful that program was (Caffarella et al. 2013).

\section{Providing seminar series in a timely manner}

The effects of a positive experience in the program and word of mouth, Bess \& Traub (2013) suggest planning upcoming programs shortly after a current program. O’Neill, (1993) found that providing follow up classes is a good strategy to keep clients coming back for more. This report found that scheduling programs in a seven-week time frame has been successful. Also successful, had been inviting a group of seminar participants back again for a class reunion where there is a speaker and light refreshments.

\section{Needs Identification/Preferred topics}

Knowing more about the nonindustrial private forest landowner will enable extension personnel to create effective outreach and educational programs (Downing \& Finley, 2005). There is little research pertaining to the educational needs of the nonindustrial private forest landowner. Gaining knowledge of these needs will lead to effective educational programming techniques (Downing \& Finley, 2005). Caffarella, (1982) found that an important component in the design of educational programs is identifying the educational needs of those attending. Needs assessment are a systematic way of establishing these educational needs. Needs assessments can be done in many ways, through highly structured techniques such as surveys or informal means such as open discussion over coffee (Caffarella, 1982). Once these needs have been identified the process is not over. The data must be analyzed, and priorities set to then create an action plan to meet the current educational needs of the participants (Caffarella, 1982).

Among various need assessment instruments Caffarella, (1982) found surveys to be the valid and reliable method in which to conduct a needs assessment, as it is a good instrument to reach a board range of individuals. Lee's (2005) work regarding the creation of professional development programs, found that these programs must be developed with the participants needs in mind. 
Program participants must be considered partners throughout the educational process beginning with planning their learning experience, offering feedback and evaluation of the program (Lee 2005). Educational needs assessment of the private forestland owner have been performed throughout the United States and surprisingly, throughout the years the findings have remained relatively similar year to year and within the nation. The top selected topics were wildlife management, insects/diseases, marketing, harvesting, and best management practices (Baughman, Cervantes, and Rathke 1998, Birch 1997, Downing and Finley 2005, Grado, Measells, Habig, and Capella 2002, and Measells et al. 2006).

Billingham (2014) argues that offering potential learning choices can be rooted in participatory decision-making grounded in Social Learning Theory, Participating Management and Participatory Democracy theory. Billingham (2014) suggests that this process can be used by group leaders, organizations, movements' school districts and even countries. Participatory decision-making encourages and involves employees or communities to share in the decision making for an organization. This can build trust and confidence in the decision maker. By engaging in participatory decision making the leader is building community, ensures compliances, improves inclusion and better decisions are made (Billingham, 2014). This type of process can be seen as respectful and ensure that diverse views are being noted (Billingham, 2014).

Measells et al. (2006) suggest that to develop an effective outreach and education strategy extension professionals must gain some insight to landowners' past forestry related experiences as well as their future educational interests. One way to gain this insight is through sending out questionnaires and conducting focus groups. Zobrist \& Rozance (2015) conducted a survey of small forest landowners to rank their interest in thirty forestry educational topics. These topics also included a brief description. The top ranked topics were forest health, wildlife habitat, fire, forest taxes, forest safety, invasive species, estate planning, climate change, wind, forest management forestry assistance. Zobrist \& Rozance (2015) found that over six years of offering those highly ranked topics they were poorly attended, however when they offered workshops on the low-ranked topics such as non-timber forest products and tool use \& safety they found that these workshops were always sold out. They suggest taking survey results with caution and not to solely rely on them. A mix of survey, experience (personal and extension educator), literature review and stakeholder input though focus groups or advisory boards can aide in creating a 
complete picture of forestland owner interest and needs. Germain \& Malmsheimer, (2002) found similar results as Zobrist \& Rozance (2015). They compared educational preference of forest resources managers with attendance records from workshops to find if survey respondents attended their indicated preferred topic. They found that the percentage of respondents to attend the topic of interest was small.

While needs assessments are helpful it has also be suggested that ideas for training and education programs do not always involve needs assessments (Caffarella et al. 2013). Topics/ideas can be generated by performance or product review, social indicators or informal interaction with community members, colleagues, acquaintances and friends. "Many highly successful programs have no needs assessment component” (Caffarella et al. 2013).

\section{Factors that influence motivation and pose a challenge to learning}

Even before a woodland owner can participate in seminar development, they must have the motivation to learn and surpass the challenges.

\section{Motivations to learn}

When considering attendance, outreach professionals must realize that motivation to learn is non-static and complex.

The Spears and Moker model of self-directed learning shows that learning is motivated by opportunities a person finds in the environment, the persons past and recent knowledge regarding the particular interest and by a chance occurrence (Roberson et al. 2005). People tend to contact with others with common interest (McPherson et al. 2001). In an attempt to broaden their landowner audience, Kuipers et al. (2013) categorizing woodland landowners into homogeneous subgroups according to land use objectives. It was shown that the forestry community tends to interact with landowners who are somehow already involved in forest management, while those that are less active are neglected (Kuipers et al. 2013). This can be noted as an external incentive factor in motivation to learn (Roberson et al. 2005). An external incentive such seeing someone else learning/using the particular tool the learner becomes curious about, will therefore engage the person to learn more about it. For example, during harsh weather when one is stuck inside, they may see a friend or relative using the computer and this 
becomes appealing (Roberson et al. 2005). This can be the same for the woodland owner. If a woodland owner sees another managing for invasive species they may do the same. "Birds of a feather flock together". Homophily is defined as contact with similar people occurs at a higher rate than among dissimilar people (McPherson et al. 2001). A North East Forester Association study found participants who attended volunteer training programs where landowners spent time together were encouraged to learn more when finding out how others manage their land (Petersen 2006).

Forestry professional being included in the learning experience is also a motivation factor for woodland owners to attend educational events. Downing \& Finley, (2005) explored what private forest landowners want in an educational program and found that networking with professionals is between somewhat and very important to them (Downing \& Finley, 2005).

The learner having a genuine trust towards the facilitator was emphasized as an effective factor in outreach. The credibility of the host agency is important to as it remains a place to turn to when a landowner needs new information (Petersen, 2006). Students want authentic trusting relationships with the teacher (among being treated with dignity and being spoken to with honesty and warmth) (Cornelius-White, 2007). When considering what makes youth return to an ongoing program a team of Extension professionals explored, among other questions, why these youth continue to return to a 4-H afterschool program. Ferrari \& Turner (2006) found that a caring adult, the physical and psychosocial environment, program opportunities and fun were the drivers to continued participation in a group. The learning, friends, homework assistance and character development were secondary. This study also found that the youth found a sense of belonging and safety and still received the academic support they wanted and needed all while have a bit of fun.

Motivation to learn can be explored by looking through the lens of Self-Determination Theory as one is found to engage in an activity fully wanting and choosing to as opposed to being told or feeling pressure to (Deci, 1992). Self Determination looks are motivation being intrinsic or extrinsic. Intrinsic motivation is interest that comes naturally to a person; "Freely doing what interests them", categorized by concentration and engagement (Deci, 1992). If a person's needs aligned with the activities, the person will experience interest. While an extrinsically motivated person participated in an activity as a means to an end, it is an instrument 
to achieve some outcome. Extrinsically motivated behavior can be a personal choice or can be chosen by someone else (Deci, 1992). Offering choice can aide in determining the intrinsic motivation of the woodland owner. Providing people with choice, thus acknowledging their perspectives or feelings enhances intrinsic motivation and interest (Deci, 1992). According to Garrison model (1997), Student Directed Learning is accomplished by three dimensions interacting with each other: self-management, self-monitoring, and motivation. Garrison explained that self-management involved learners taking control of the learning context to reach their learning objectives. The learner's control does not mean independence, rather collaboration with other people within the context. A person experiences interest when they are taking part in new, challenging and aesthetically pleasing activity that satisfies their basic psychological needs and promotes development (Deci, 1992). When students find meaning in the learning and feel no pressure, they often find the information more stimulating and absorb the information more fully (Deci, 1992).

A desire to contribute to society and to the next generation has been found to be a motivator to learner. The Roberson \& Merriam, 2005, study examining the process of learning found that many learners spoke of learning so they may be able to contribute to society and for the next generation.

\section{Challenges to learning}

By understanding the perceived challenges people have to learning, educators can begin to remove these challenges thus creating well attended educational events.

Measells et al. (2006) found there are three main challenges why nonindustrial private forest landowners may not attended educational programs, 1) being unaware of the existence of the educational program, 2) lack of time 3) lack of interest. Other barriers were found during woodland owner focus group conducted by Andrejczyk et al. (2016). They found that some landowners may not be responsive to outreach efforts if they are in some way already managing their land. Barriers also include the reciprocal or opposite of all that motivates one to attend educational seminars. There may be other motives for attending seminar that are not listed as this was not a comprehensive list. 
Adults perceived barriers to participation in educational programs can be identified as situational, institutional and disposition factors (Porras-Hernandez \& Salinas-Amescua, 2012), which can be supported by Vanderford et al. 2014 as they found that proximity plays an important role in attendance. There may be a limit to how far a West Virginia woodland owner is willing to travel as a study by Downing \& Finley (2005) found that 55\% of private forest landowners studied were willing to travel 45 minutes or more to attend a program (Downing \& Finley, 2005).

Downing \& Finley (2005) recommend considering the age of the audience when planning educational events. It can be noted that as of 2013, the average age of the primary owner of West Virginia woodlands was 64 years old with an average age of 60 for the secondary owner. Less than $7 \%$ of the West Virginia family forest and woodland primary owners are under the age of 45 and $5 \%$ of the secondary owners are under age 45 (National Woodland Owners survey, 2013). Roberson and Merriam, (2005) found a late change in life (retirement being the biggest) is a "catalyst that spurs one to learn more". Learning is a response to one situation in life and a particular life stage. Life transitions are often a motivator of self-directed learning. Changes related to time, family and loss (physically and socially) play a large role in one motivation to learn and this can be considered an interval incentive for self-directed learning (Roberson \& Merriam, 2005).

Knowing the age and life stage of the intended audience may influence how education information is provided. Identifying a woodland owner's preferred mode to receive information regarding forest management can play a role in how extension provides information to the landowner. Of the 277 West Virginia private woodland owner surveyed in the National Woodland Owners Survey, 55\% preferred written materials, 37\% preferred to talk with someone, $23 \%$ favored a visit by an educator to their land, $10 \%$ preferred workshop and $21 \%$ did not want or need information. A class that is adaptive to the changing age of the woodland owner motivates the participants to learn (Petersen, 2006). Downing \& Finley, (2005) found private forest landowners preferred an active learning style with class delivery methods that include workshops, demonstration areas and skill demonstrations (Downing \& Finley, 2005). A survey of Ohio tree farmers regarding their forest management outreach needs found that they preferred receiving information at in-person events or from publication as opposed to email and webinars (Starr et al. 2014). Just as important as delivery method, Goote et al. 2010 found that the 
materials offered in an educational program must be practical, relevant and lead to tangible outcomes for adult learning to remain engaged. In contrast to this, a survey conducted by Rozance et al. 2015 found that forest landowners preferred written communication as a means of receiving forestry information while face-to-face assistance were the least favored means of receiving forestry information. However, it is noted that there is some variability when it comes to preferred means of receiving information and remaining diversified in the delivery of materials is key to reaching forest landowners.

A lack of resources can be a deterrent to learning. In West Virginia many woodland owners live in rural areas thus making resources challenging to receive. Resources such as mail, internet and meeting with others can be difficult at times. The learner can feel alone with a lack of resources and living in a rural setting (Roberson et al. 2005).

Gender may have an influence as to what motivates one to attend a woodland focused seminar. A study conducted by Umaerus et al. 2013 revealed that Swedish women's involvement in forestry activities has been limited as it is well-documented that there is a maledominance in traditional family farms. When planning educational events it may be warranted to consider gender. Downing \& Finley (2005) found gender to be a significant consideration as founded in their study done regarding private forest landowners and what they want in an Educational program. Porras-Hernandez \& Salinas-Amescua, 2012 explored why there was low participation rates in an adult education geared to mestizas' women and Native women in two regions of Mexico. Going into the study the researchers thought these women would have a poor self-concept, yet as their research progressed, this was not the case (Porras-Hernandez \& SalinasAmescua, 2012). Some of the conclusions of this study suggests that many of the women studied had high self-concepts showing pride and love for school. Many dropped out of school for economic reasons, own decision or family issues (Porras-Hernandez \& Salinas-Amescua, 2012).

Date and time plays a role in whether a potential participants will attend an educational event. A study done by Downing and Finley (2005) found that 34\% of individuals preferred evening meetings and that $46 \%$ preferred after 5:00pm. Tuesday evening was noted as the preferred day of the week to host an educational event. Monday where only $27 \%$ of nonindustrial private forest landowners' preferred (Measells et al. 2006). The Downing and 
Finley, (2005) study did find that forest landowners in Pennsylvania ranked Mondays as the second preferred evening. Scheduling a seminar on the weekend (was found to be undesirable days for seminars), scheduling conflicts and length of programs (short time preferred) play an important role in attendance (Vanderford et al. 2014). Through delivering focus groups and questionnaires to South-Central U.S. woodland owners, Measell et al. (2006) found that 46\% preferred evening programs while $34 \%$ preferred morning programs. It was also found that two hours was the best length of time for an educational seminar (29\%) while half-day program was the second favored length of time. Fifty eight percent of these woodland landowners were interested in attending a forestry related program that would be held during consecutive weeks for a short time (Measell et al. 2006).

By understanding the West Virginia woodland owner, educators are able to tailor the educational event, content and language to the potential learners. Direct mail has been shown to be an effective means of contacting to these landowners. It also has been shown to be a highly variable means of ensuring that landowners are receiving the message that is being sent to them. Whatever the mode of outreach, learner participation in the development of seminars has an impact on attendance to education events. It is also important to understand what motivates and challenges woodland owners to attend an educational event. The diversity of woodland owners and the complexity of the motivations and challenges of learning, points to the importance of continued research in creating educational opportunities that are well attended and satisfy the woodland owner's educational motives 


\section{Chapter 3: Methods}

A three-part evening woodland-focused education seminar series was developed to test how seminar attendance is influenced when woodland landowners are involved in topic selection. This study examined attendance by analyzing how it is associated with these variables: topic selection, contact level by direct mail.

This study was completed in three West Virginia counties: Greenbrier County, Ritchie County and Hampshire County. County selection was based on the availability of the tax records for that county (Dunn et al. 2006), the cooperation with the county agent and to provide a physical separation to minimize cross county communications. For each county, 1200 woodland property owners of 10 acres and greater were randomly chosen, for a total of 3600 woodland landowners. Woodland owners from each county were randomly split into three treatment groups of 1200 with varying direct mail contact types.

\section{Treatment Groups}

Within each county, woodland owners randomly selected for this study were randomly split into one of three treatment groups (Table 1.). These treatment groups were:

1. Topic participants (TP)

2. Pre-notification $(\mathrm{PN})$

3. Invitation only (IO) 
Table 1. Treatment Groups with type of direct-mail contact each group received.

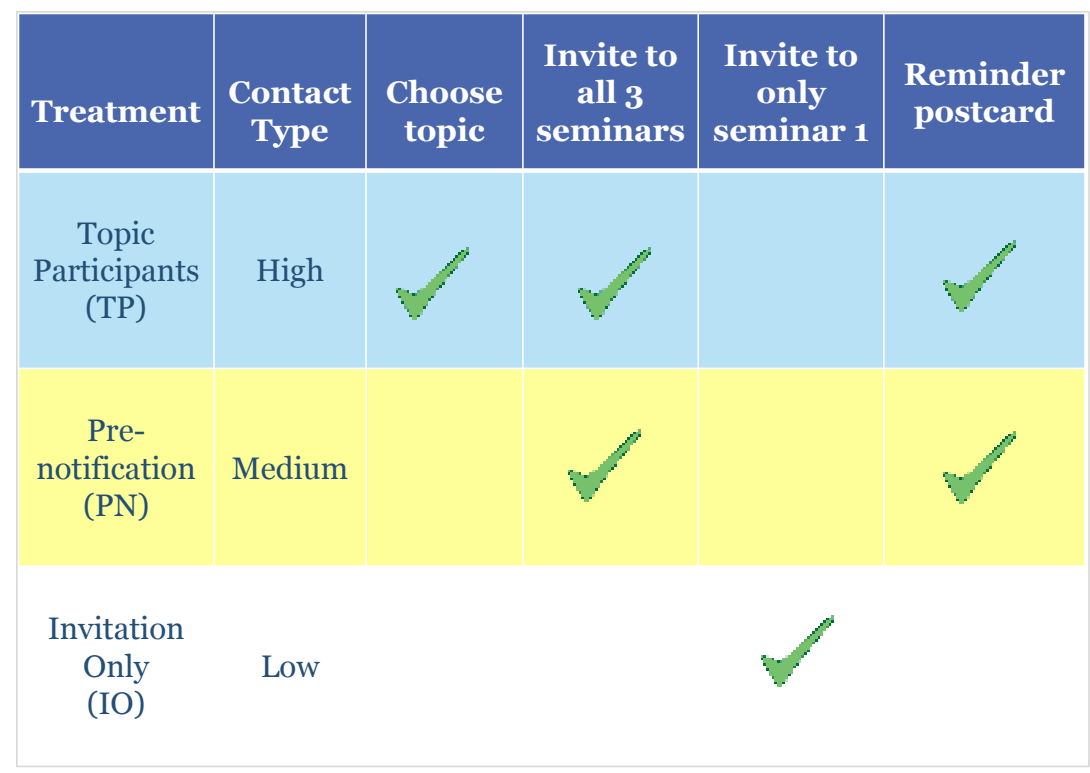

The TP treatment group had the highest level of contact as they received all four types of direct-mail contact. The medium contact level was the PN treatment with three direct mail contact types. The IO treatment group was the low contact level as they received only one direct-mail contact type.

The TP group (400 per county) was sent an introductory letter and it included a topic selection postcard to the participant-designed Seasons in the Woods education series. The introductory letter outlined the intent of the series, the three dates of each seminar, what county it would held in, registration information, and a set of brief instructions regarding the topic selection return postcard (figure 1). The pre-posted, coded, self-addressed, blue postcard included the list of topics to choose from. Topics they could select were: Create more productive woodlands, Butterflies to bats, How much is your timber worth, Ask the experts, Climate change in West Virginia and Medicinal herbs of West Virginia. There was also a blank space for participants to write a topic of interest that may not have been on the list. This postcard also included two additional questions; inquiring whether the recipient was interested in attending the three part series and if not, why? And how many people will be attending the seminar? (Figure 1 and 2). 


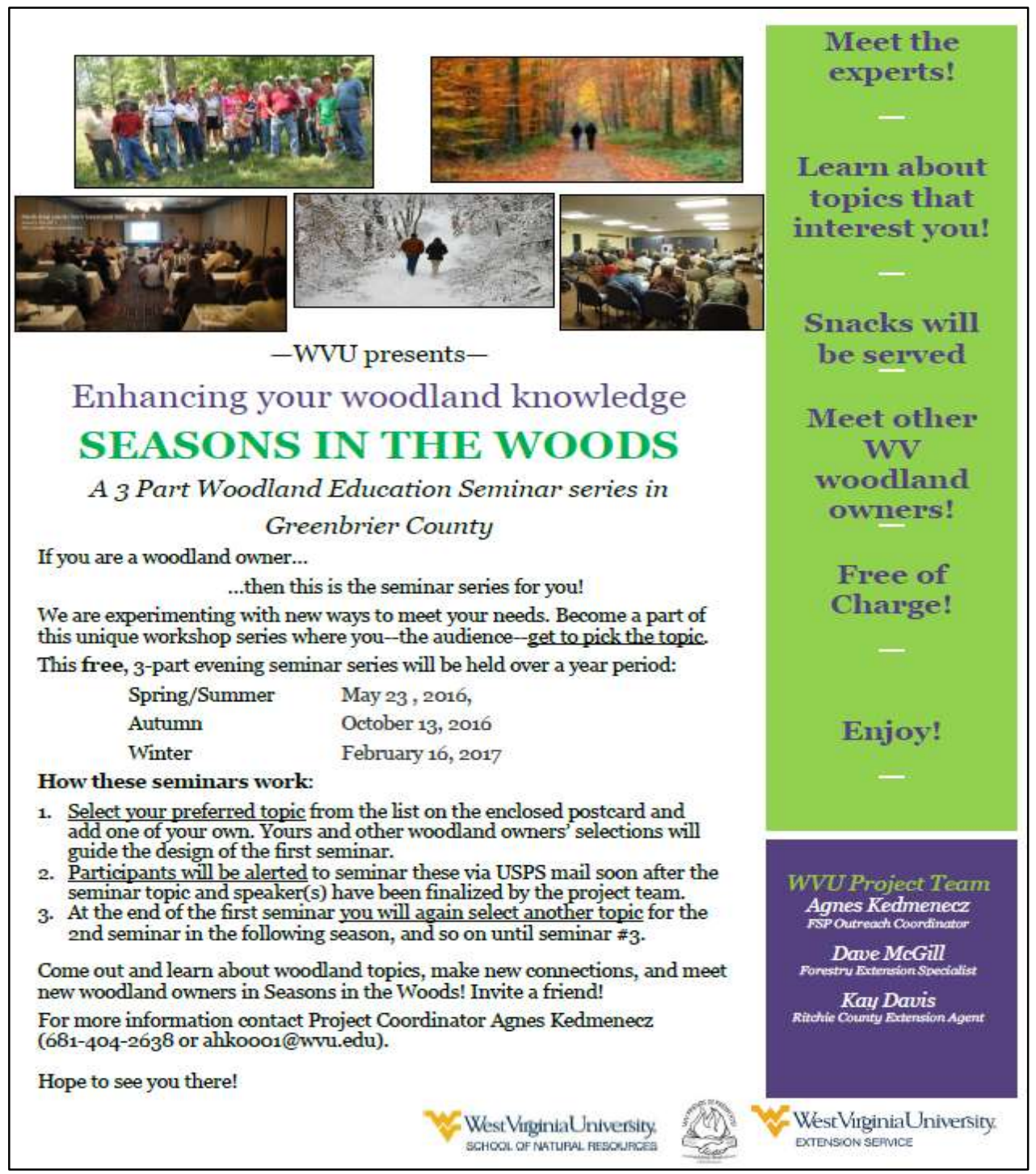

Figure 1. Introductory letter for the Topic Participant group 


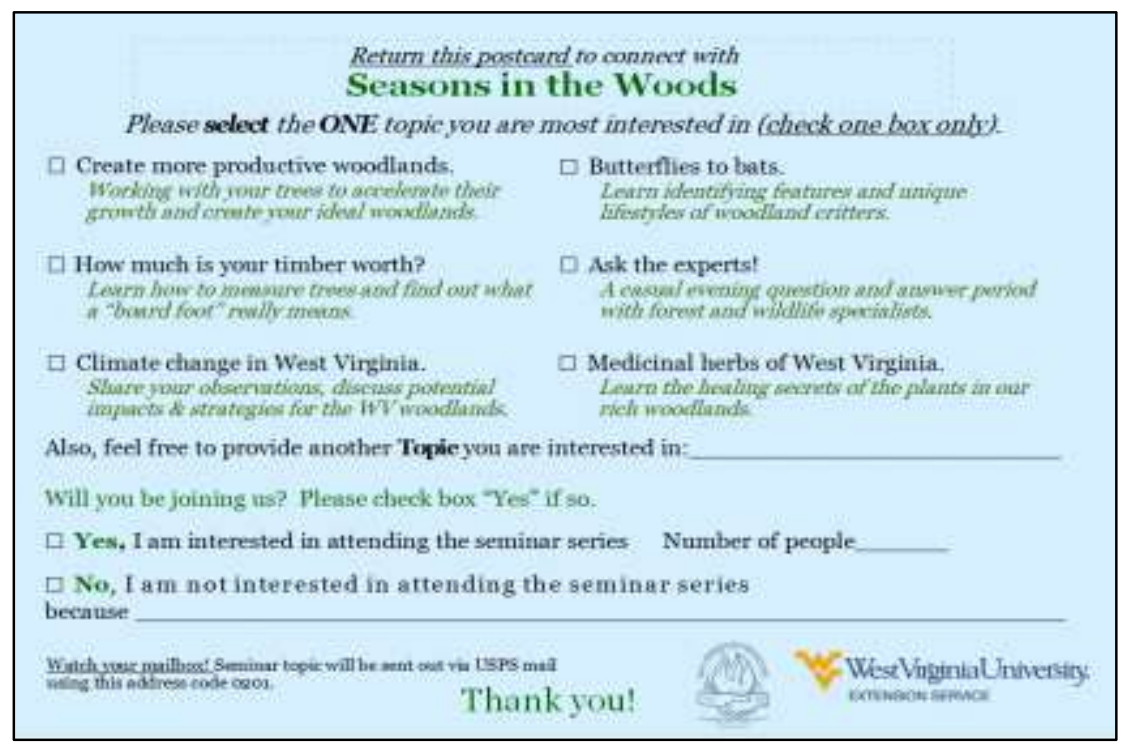

Figure 2. Topic selection with response postcard for the Topic Participant group

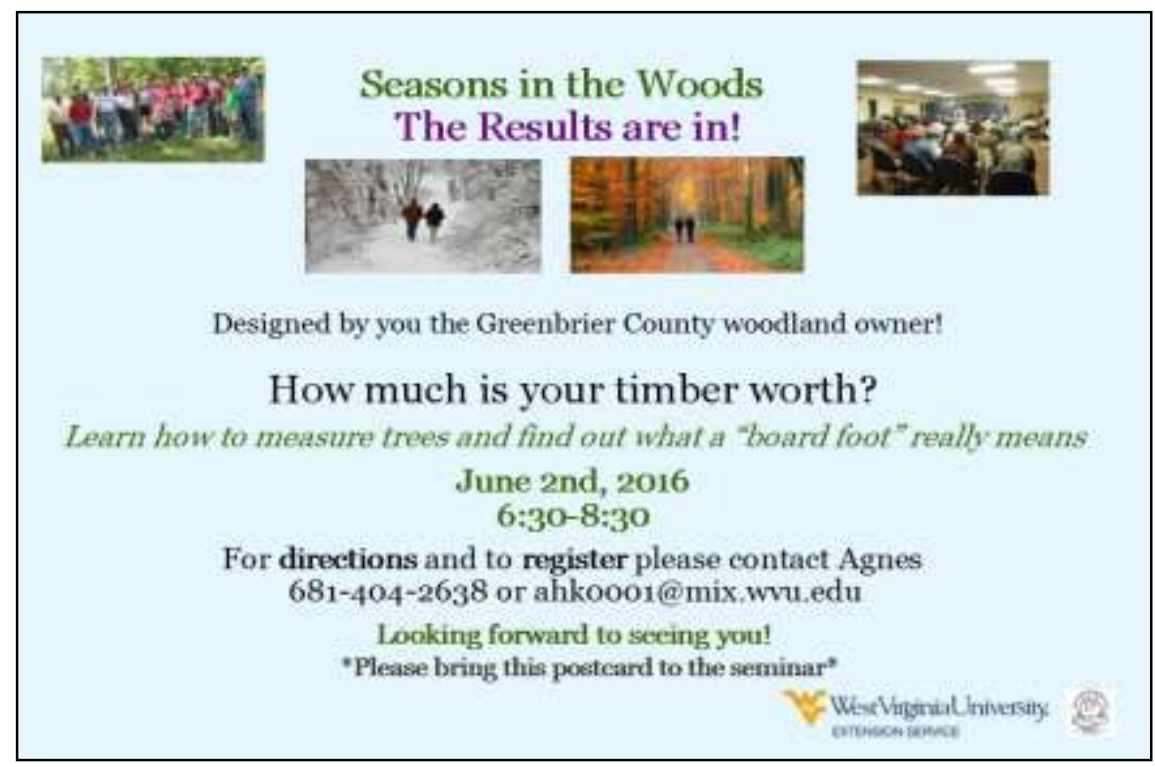

Figure 3. Seminar one reminder postcard for the Topic Participant group 
The PN group of 400 per county was also sent an introductory letter and a postcard invitation, however this postcard did not include a list of topics (see Figures 4 and 5). The preposted, coded, yellow postcard was self-addressed enabling the landowner to express interest in attending the three-part series and number of people that will be attending. The introductory letter outlined the intent of the series, provided the three dates of the seminars in each season, what county it would be held in and registration information.

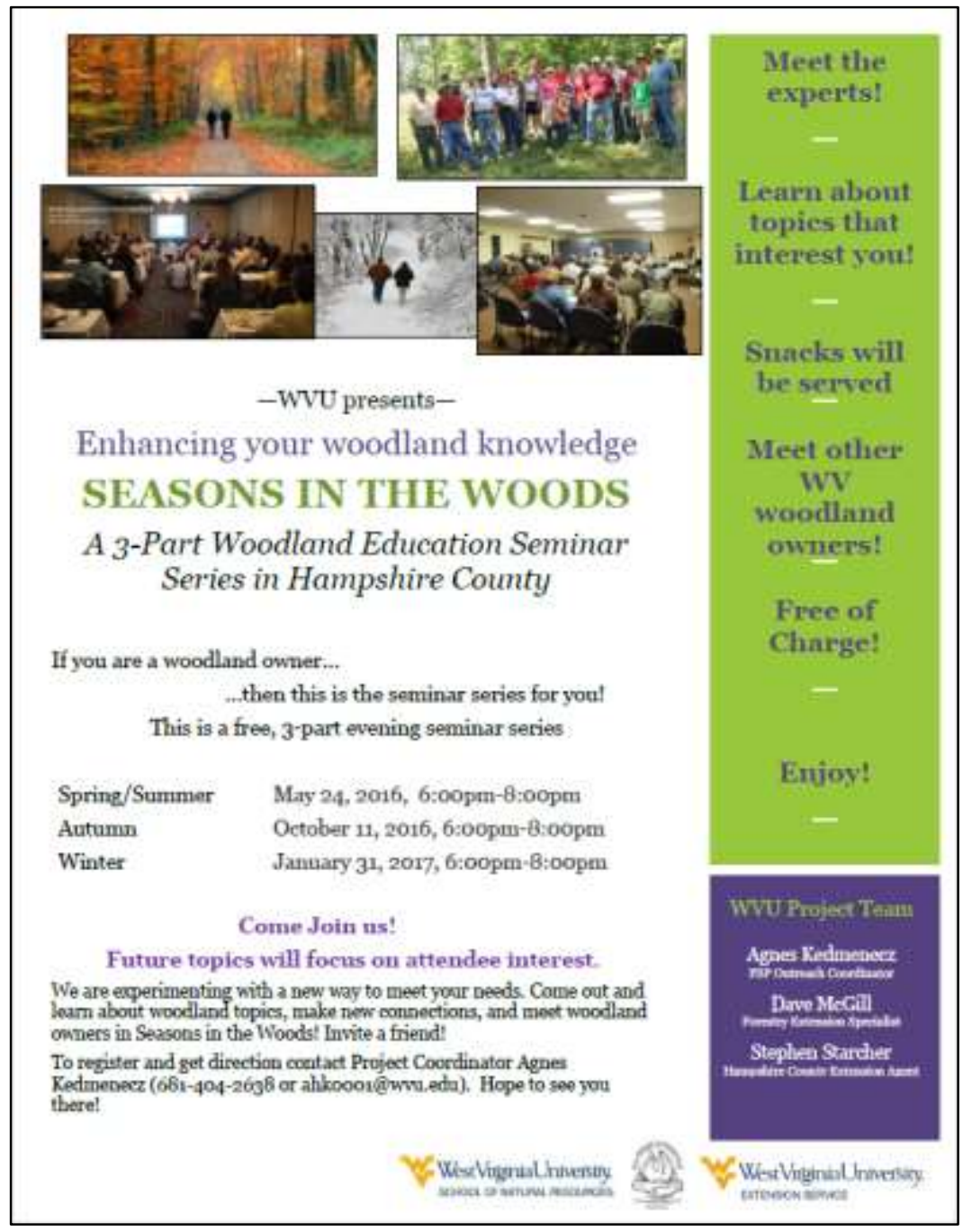

Figure 4. Introductory letter for the Pre-notification group 


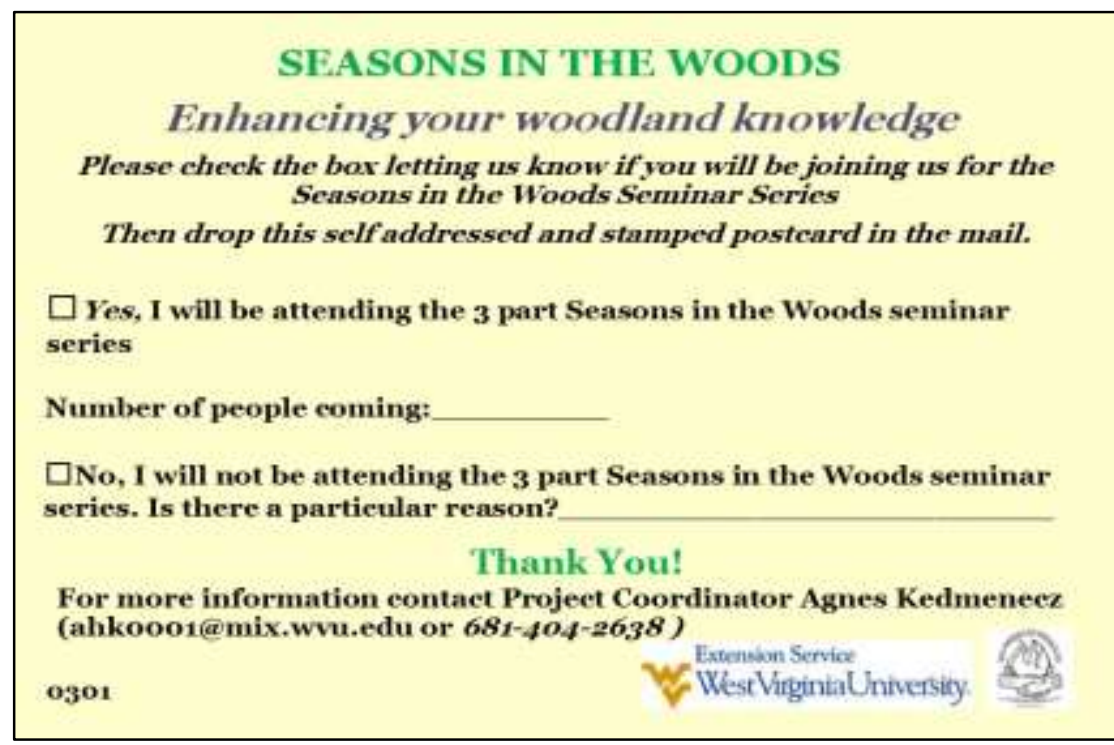

Figure 5. Response postcard for the Pre-notification group

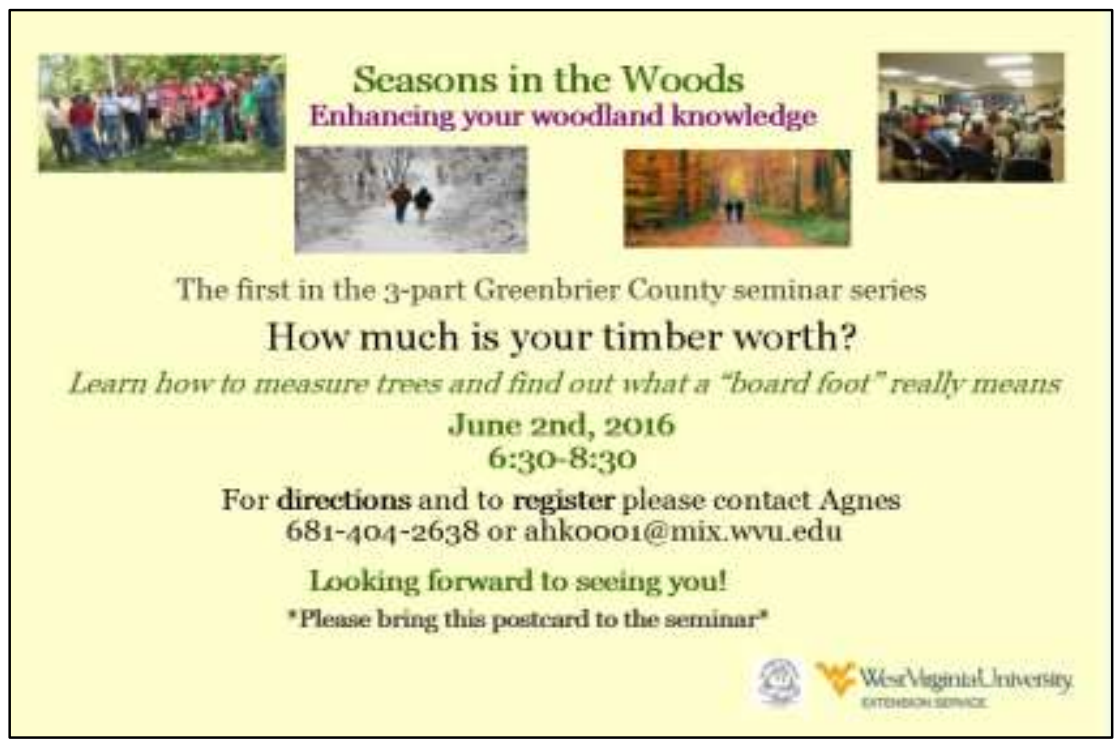

Figure 6. Seminar reminder postcard for the Pre-notification group

The TP and PN introductory letters with invitation postcards were mailed out on March 14, 2016, from the West Virginia University mail room. From this mailing, bad addresses were returned and readdressed. These readdressed letters and postcards were mailed out on April 14, 2016. 
The third treatment group, Invitation only (IO) was not sent an introductory letter, only a white, coded postcard inviting them to the first seminar. This postcard invitation included date of seminar, topic, what county the seminar will be held as well as registration information. Woodland owners interested in attending were instructed to call or email to register. This treatment group was considered the control group as it represented the standard direct mailing mode of inviting landowners to seminars by West Virginia University extension (figure 7).

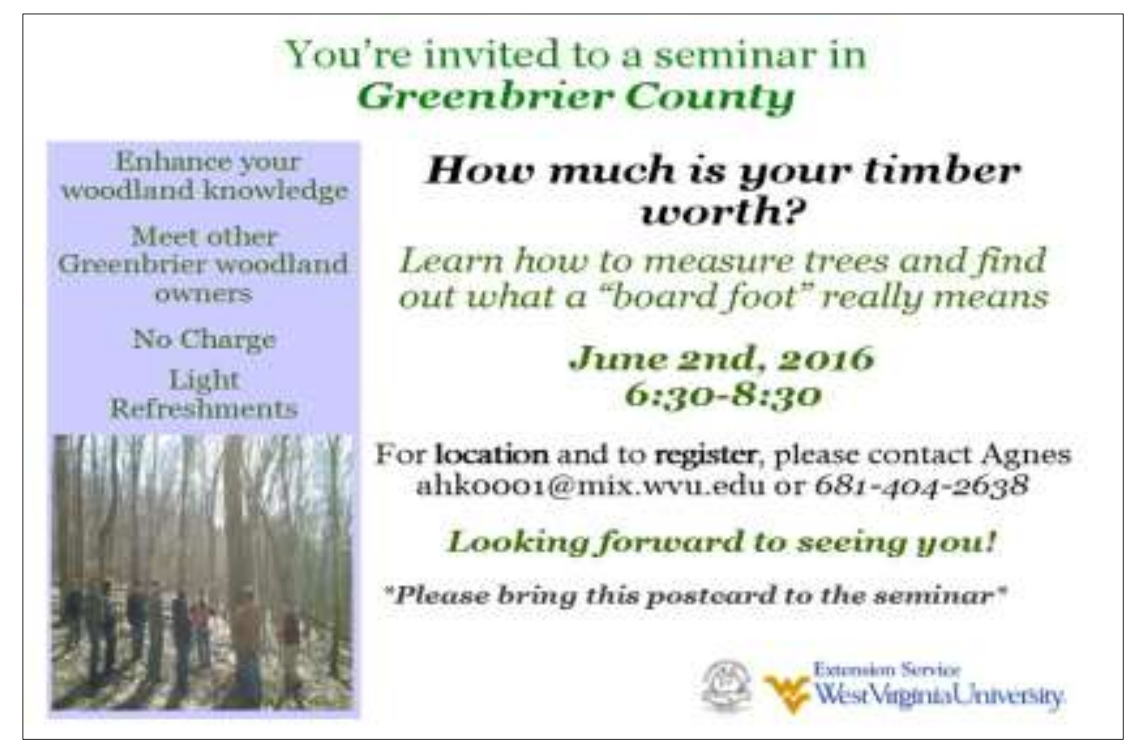

Figure 7. Seminar Postcard invitation for IO group

The IO postcard invitation along with the reminder postcards to all the PN and TPs who expressed interest in the seminar series or did not responded were mailed out May $9^{\text {th }} 2016$. The bad addresses and the 28 participants who indicated no, they were not interested in attending the series, did not get a reminder card (figure 8). In total 4649 mailings were sent prior to the first seminar.

Direct mail was the mode in which this study reached out to the woodland landowners. However, two counties inadvertently diverged from this method. The Greenbrier County extension educator placed a Seasons in the Woods poster up in the extension office the week of 
the seminar. In Hampshire County the first seminar was advertised the in the local paper. It is unknown how it became posted in the newspaper.

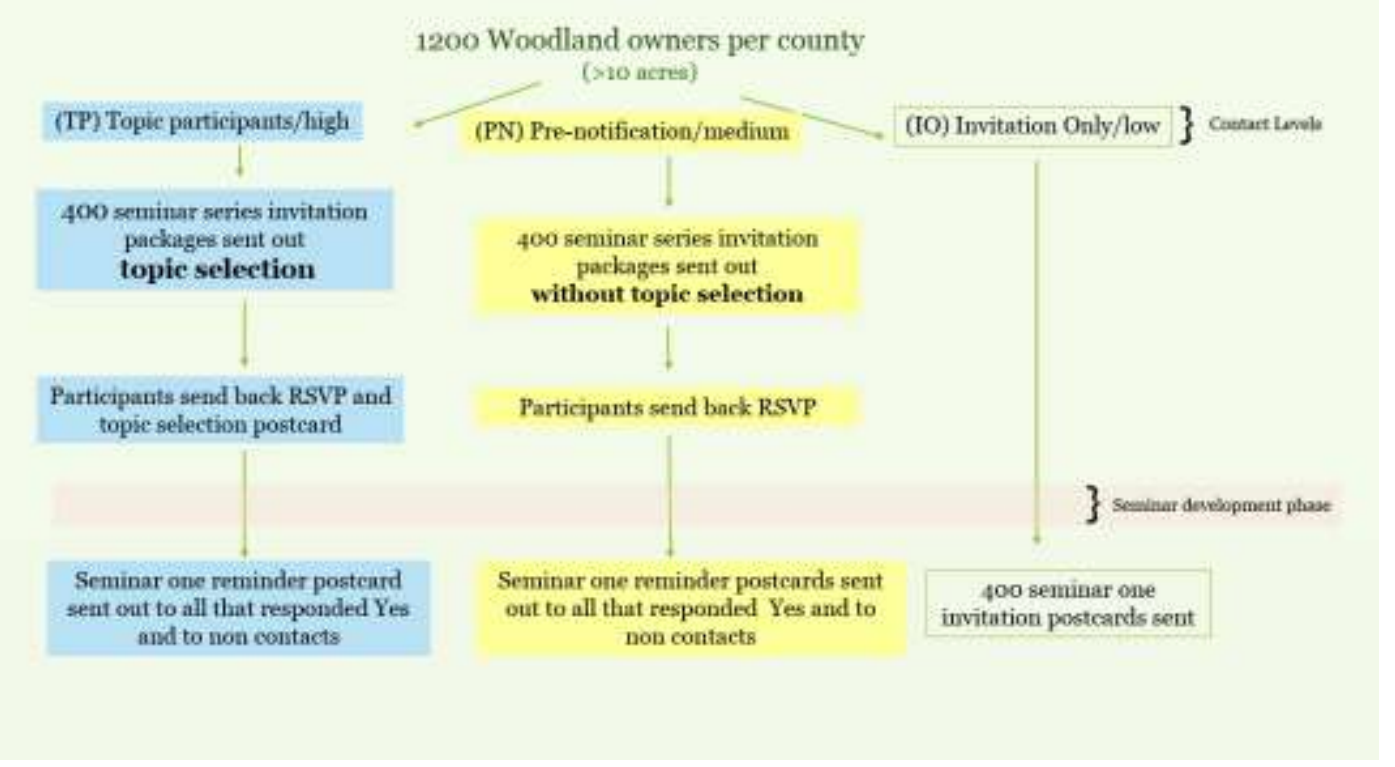

Figure 8. Illustrated delivery method of the first seminar for the three treatment groups.

\section{Postcard topic selection}

The topics chosen for the TP group's topic selection card were Medicinal herbs of West Virginia, Bats to butterflies, How much is your timber worth, More productive woodlands, Meet your forester, and the sixth topic was Climate change in West Virginia. To encourage inclusivity, the topics offered to landowners reflected gender interests of West Virginia male and female woodland owners that were found in a recent master's thesis by Fegel (2014). Medicinal herbs and Bats to butterflies were generally preferred by females while How much is your timber worth and More productive woodlands, were generally preferred by males. The Meet your forester, and Climate change in West Virginia topics were not based on male/female preferences but based on facilitator interest.

\section{Seminar implementation}

The seminar was designed based on the topic selection postcards return by the TP group. There was 33 days between mail out of the topic selection postcard and ranking of the topics. This ranking was categorized by counting the frequency of the topics selected by the TP landowners who sent back the topic selection postcard. 
Once the topic was determined for each county, the invitation postcard for the IO's and reminder postcard for TP and PN's who expressed interest in attending or who did not respond were mailed out May 9, 2016.

Woodland owners interested in attending the seminar series were instructed to register via phone or email. Registrants' names and phone numbers were recorded as they registered.

Attendance was recorded on the evening of the seminar. Participants were asked to provide name, address, email and how they heard of the seminar. They were also encouraged to bring their invitation postcard with them to the seminar.

In all three counties, seminars were held on weeknight evenings: 6:00 pm until 8:30pm. These seminars began with a brief introduction welcoming participants, introducing topic and guest speakers as well as an ice breaker activity. The ice breaker for this first seminar was an acrostic (word puzzle) name game. Participants were given the word sycamore displayed vertically on a piece of paper and they were to find a participant that had a letter in their name that would intersect with sycamore till each letter of the word had a name associated with it. A prize was given to the first three participants to complete the ice breaker. Prizes included books, extension publications, t-shirts and USDA books. There were two 45-minute sets of subject content with a 15 minute break in between. This break time was somewhat flexible as we wanted to encourage landowners to talk with one another. At the end of the first seminar, participants were given an evaluation that included topic selection opportunity for the second seminar. Suggested topics were listed via PowerPoint to encourage landowners to think of topics.

Following the seminar the topic selections from the participant evaluations were compiled and ranked by frequency of topic. This determined the second seminar's topic. The methods used to implement the second seminar were similar to the first seminar. Participants registered and provided attendance upon arrival. A postcard invitation for seminar two was sent out to all IO's, those TP and PN that expressed an interest in attending, or those who did not respond. This postcard was also mailed to any New Comers (NC1) to the group that were not on the initial mailing list. There was a brief introduction welcoming participants, introducing topic and guest speakers. This seminar's icebreaker was a woodland owner "get to know you bingo". A prize was given to the first three participants to complete the ice breaker. Prizes included 
books, extension publications, t-shirts and USDA books. There were two 45-minute sets of subject content with a 15-minute break in between. This break time was somewhat flexible as we wanted to encourage landowners to talk with one another. At the end of the second seminar, participants were given an evaluation that included topic selection opportunity for the third seminar. Suggested topics were listed via PowerPoint to encourage landowners to think of topics.

The topic selections from the seminar two participant evaluations were compiled and ranked by frequency of topic. This determined the third seminar topic. Guest speakers were arranged. The postcard invitation for the third seminar to Hampshire County participants were sent out January 19, 2017 from the WVU mail room (see Figure 9). The postcard invitation for the third seminar for Ritchie and Greenbrier County were mailed out from the WVU towers mail room on January 30th. This postcard was mailed all the IO group, those that responded yes they are interested in the three part series, and to those that did not respond from the TP and PN group This postcard was also mailed to any New Comers (NC1 and NC2) to the group that were not on the initial mailing list.

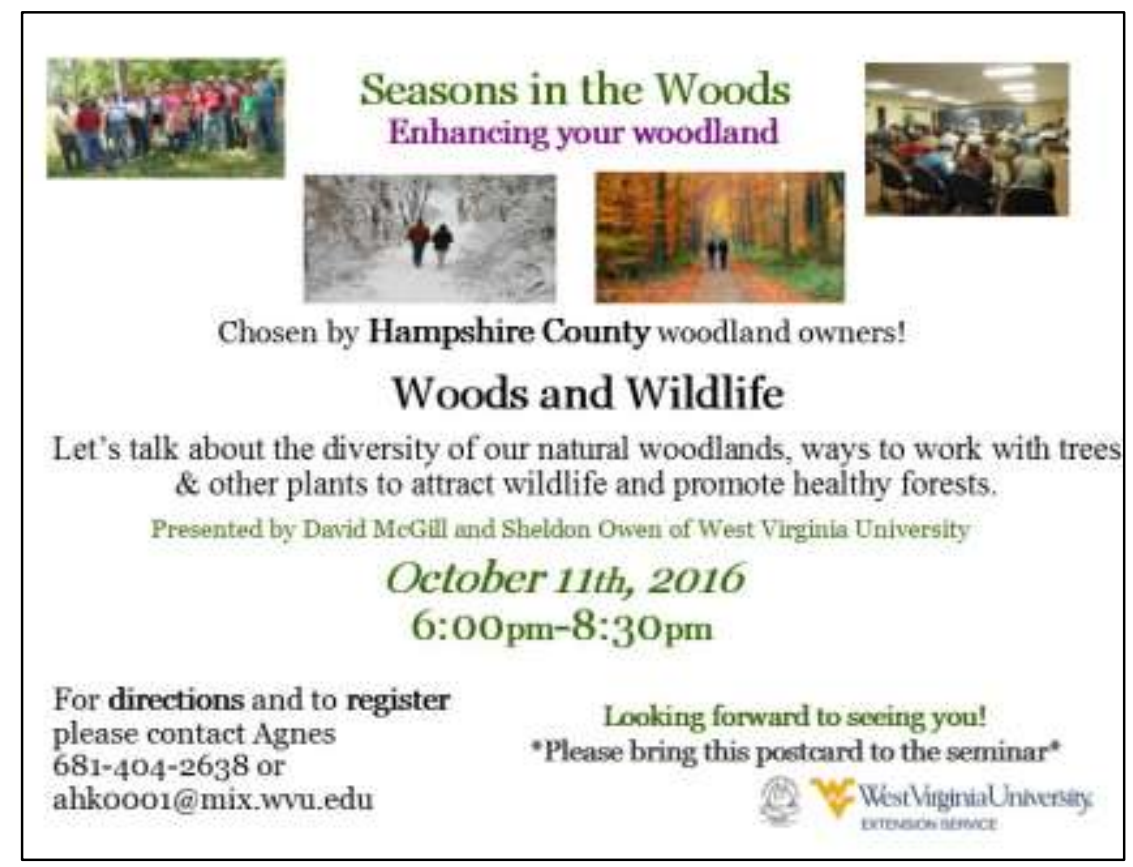

Figure 9. Example of postcard invitation for seminar two taken from Hampshire County 
Seminar three was implemented using the same method as seminar one and two. A postcard invitation for seminar three was sent out to all IO's, those TP and PN that expressed interest in attending or did not responded and to NC1's and NC2s (Figure 10). Participants registered, provided attendance upon arrival to seminar. There was a brief introduction welcoming participants, introducing topic and guest speakers. As an icebreaker, participants were asked to introduce a member of the group after finding out three things; name, what part of county they were from, and their land management objective. There were two 45-minute sets of subject content with a 15 minute break in between. This break time was somewhat flexible as we wanted to encourage landowners to talk with one another. At the end of the third seminar, participants were given an evaluation. Also at the end of the evening, participant names were put into a basket and randomly drawn for door prizes. The door prizes were USDA Forest Service books and educational CD's.

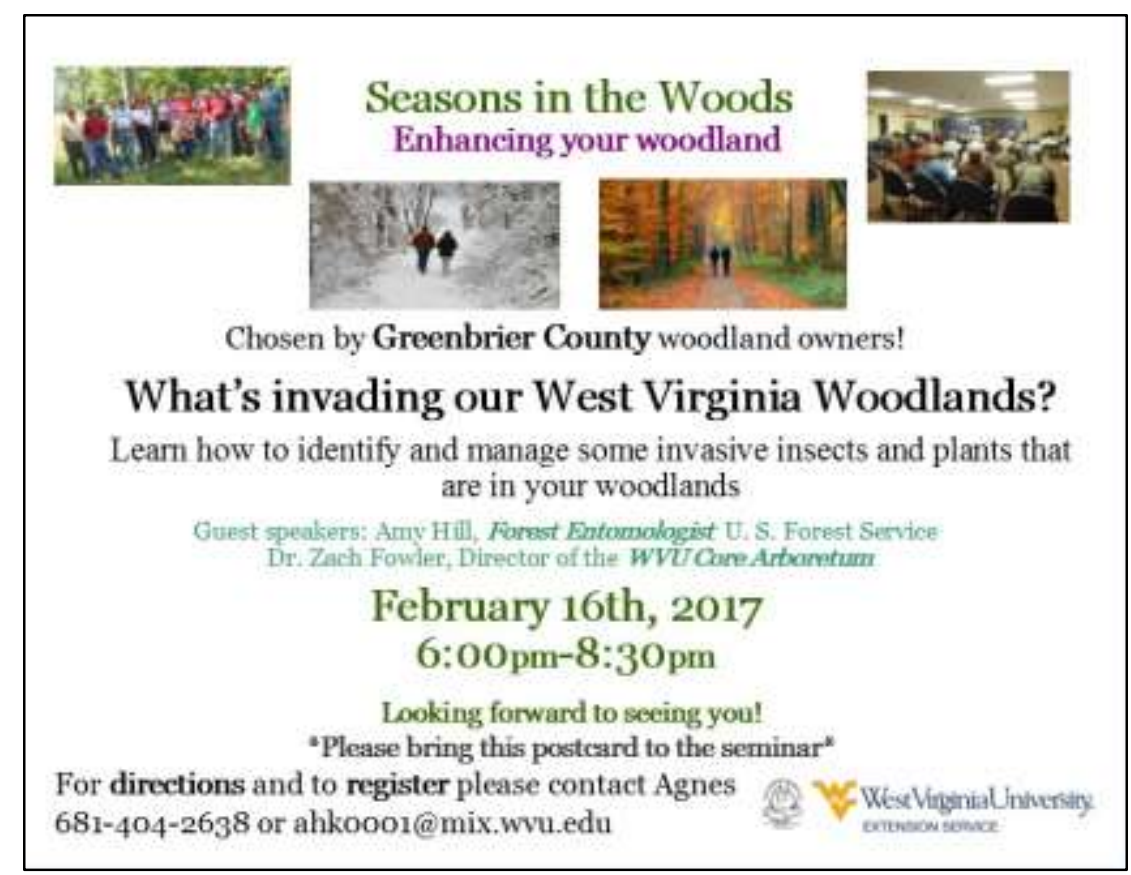

Figure 10. Example of postcard invitation for seminar three taken from Greenbrier County 


\section{Statistical Analysis}

The first direct mailing began with the TP and PN woodland owners. This consisted of 2400 intention letters with a self-addressed postcard. Of these, 1200 were in the PN group and 1200 were in the TP group. This initial mailing did not reach all the intended participants thus were returned back by US postal services as bad address or deceased. There were 123 removed from the PN data set, 120 were bad addresses and three participants were deceased. There were 123 participants removed from the TP data, 121 were bad addresses and two were deceased. This was the only time TP and PN bad addresses were removed for analysis. It is assumed that if the mailing reached the intended address during the first mailing that it reached them for all subsequent mailings. These omissions from the data set reduced the total number from TP and PN groups of data collected to 2154; 1077 of these were the PN group and 1077 of the TP group. The first direct mailing to the IO group of 1200 was the invitation post card. There were 180 bad addresses that were removed from the original data set bringing the analysis number to 1020 for the IO group. Therefore, in total the analysis of the three treatment groups was reduced to 3174 of the original 3600. An additional category, New Comers (NC) emerged during project implementation and will also be discussed.

Effects of contact level were evaluated from two aspects. First, short term effects of attendance to the first seminar of the series were examined. These effects were to respondents' declared interest in the three-seminar series, whether they registered for first seminar, and whether they attended the first seminar. Interest, registration, and attendance served as binary response variables in these assessments. Contact level served as the primary explanatory variable of interest. Contact level included high (TP), medium (PN), and low (IO) landowner groups. Henceforth, these three categories referring to the levels of landowner contact will be referred to as TP, PN, and IO. Logistic regression was carried out using SAS PROC LOGISTIC (SAS®, Version 9.4, SAS Institute Inc., Cary, NC Copyright @2002-2012) to model these dependent variables with contact level as an explanatory variable and county as a blocking variable. Multinomial logistic regression was used where non-respondents were brought in as a reference level in the case where interest in attending was evaluated. This approach permitted the comparison of contact level (TP and PN only) with interested and not interested categories. A generalized logit link function was used in these instances and all others used the default binary logit function. 
Secondly, long-term effects of contact level were evaluated over the course of the threeseminar series. With the same group of selected participants being invited in each of the three events, seminar was treated as a repeated measure to capture variation due to potential correlation between events. SAS PROC FREQ was used to model these association between contact level and attendance controlling for county and seminar number. The Cochran-MantelHaenszel (CMH2 option in SAS) was used to account for the repeated nature of the seminar variable. Odds ratios were generated to assess the strength of significant associations using PROC LOGISTIC with attendance regressed on treatment, seminar, and county.

Because of the small sample size of direct mail respondents in this study along with the even smaller attendance, our significance level was set at alpha=0.10 to assess any possibility of statistical significance between variables. In addition, we report exact p-value in each statistical test. 


\section{Chapter 4: Results \\ Evaluation of the First Seminar}

Effects of topic selection on interest, registration and attendance at the first seminar

Twenty-four hundred landowners from three counties were invited to attend the full three-seminar series called Seasons in the Woods. Twelve hundred were in the TP group and 1200 were in the PN group. There was a total of 2154 of eligible addresses after filtering out returned envelopes marked as bad addresses or deceased. Approximately 12 weeks following the mail out 98 TP and PN had sent back their response postcards (PN (n=44) and the TP group $(n=54))$. This represented an overall response rate of $4.6 \%$. For both TP and PN groups, the response postcards indicated a yes or no to woodland owner interest in attending the three-part education series. Forty-four responses (4.1\%) were received from the 1077 eligible landowners in the PN group. Fifty-four responses (5.0\%) were received from the 1077 eligible landowners in the TP group. There was no significant association between whether a landowner was in the TP group or PN group and the likelihood of returning a response postcard, $\chi^{2}(1, n=2154)=$ $0.11, \mathrm{p}=0.3$ (Table 2.).

Table 2. Logistic regression analysis of topic selection on response, interest, registration, and attendance of first seminar. Significant odds ratio $>1$ suggests topic selection resulted in higher likelihood of behavior. $\mathrm{TP}=$ topic participants who had been given the chance to select a seminar topic at the first meeting. $\mathrm{PN}=$ pre-notification group who were notified of three-seminar series.

\begin{tabular}{|c|c|c|c|c|c|}
\hline \multirow[t]{2}{*}{ Comparison: TP vs PN } & \multicolumn{4}{|c|}{$90 \%$ Conf. Interval } & \multirow[b]{2}{*}{$\begin{array}{l}\mathrm{p}- \\
\text { value }\end{array}$} \\
\hline & $\begin{array}{l}\text { Odds } \\
\text { Ratio }\end{array}$ & Lower & Upper & $\begin{array}{l}\text { Chi- } \\
\text { sq }\end{array}$ & \\
\hline \multicolumn{6}{|l|}{ Among all woodland owners in sample } \\
\hline ...returning a postcard & 1.237 & 0.879 & 1.741 & 1.05 & 0.306 \\
\hline ...indicating interest in seminars & 1.983 & 1.268 & 3.103 & 6.34 & 0.012 \\
\hline ...registering for seminar & 0.723 & 0.375 & 1.397 & 0.65 & 0.418 \\
\hline ...attending a seminar & 1.093 & 0.563 & 2.122 & 0.05 & 0.826 \\
\hline \multicolumn{6}{|l|}{$\begin{array}{l}\text { Only respondents who expressed interest in } \\
\text { attending }\end{array}$} \\
\hline ...registered for seminar* & 1.917 & 0.683 & 5.378 & 1.076 & 0.299 \\
\hline ...attended seminar* & 1.917 & 0.683 & 5.378 & 1.076 & 0.299 \\
\hline
\end{tabular}

* Registered and attended have identical analysis results because of those who expressed interest, everyone who attended had registered. 
Of these 98 respondents, there were 62 participants from the PN (n=21) and the TP group $(n=41)$ who indicated interest in attending. There was a significant relationship between contact level and interest in attending, $\chi^{2}(1, \mathrm{n}=2154)=6.34, \mathrm{p}=.012$ (Table 1$)$. The odds of a positive response when controlling for county were nearly twice as high for TP than PN groups $(\mathrm{OR}=$ $1.98,90 \%$ CI $1.268-3.103)$.

Despite this significant association, registration rates did not reflect this. Of the 62 people who responded indicating interest in attending, only 15 registered (24.2\%). Of the 15 , seven were from PN and eight from TP with no association between contact level group and registration rate among participants who indicated interest in attending, $\chi^{2}(1, \mathrm{n}=62)=1.08, \mathrm{p}=$ .30. An additional 11 participants registered for the seminars but had not responded to the initial mailing. Overall, 26 (1.2\%) participants registered for the first seminar of the total 2154 combined TP and PN treatment types. There was no significant association between treatment and registration rate as there were $11 \mathrm{TP}$ and $15 \mathrm{PN}, \chi^{2}(1, \mathrm{n}=2154)=0.65, \mathrm{p}=.42$.

There were 25 of the TP and PN group who received the initial mailing and attended the first seminar. This is an attendance rate of $1.16 \%$ as there were 12 TPs and 13 PNs. The proportions of people who had indicated they were interested and who actually attended the seminar $(n=62)$ were equally distributed among the two treatment groups $\chi^{2}(1, n=62)=1.08, p$ $=.30$.

\section{Effect of topic selection on attendance of the Topic Participants $(n=41)$}

For this subset, choices of seminar topics received from the 41 TP response cards were ranked based on which topic was the most frequently selected. This decision could positively or negatively affect the number of registrants and actual attendance based on whether or not the individual's topic was presented.

Although statistically not significant, a participant was almost three times more likely to register for a seminar if their topic had been selected for the seminar $(\mathrm{OR}=2.81,95 \%$ CI 0.48 16.56). Five of the 21(23.8\%) TP participants whose topic was selected for the seminar, registered, while only two of the 20 (10\%) TP participants whose topic was not selected registered. 
The five participants whose preferred topic was presented actually attended the seminar. There were three participants who did not get their preferred topic presented but still attended the seminar. There was no significant association between topics being selected and attending the seminar (Fisher's exact test, $\mathrm{p}$-value $=0.696)$ even though the odds ratio $(\mathrm{OR}=1.77,95 \% \mathrm{CI}$ 0.362-8.647) indicated a trend in a higher likelihood for those whose topic was selected in attending the seminar. Odds attending the seminar were 1.77 times higher for those whose topic was selected than those whose preferred topic was not presented.

\section{Effect of treatment on likelihood to attend the seminar}

There was a total of 35 participants registered for the seminar from the three treatment groups (TP, PN and IO) including nine IO participants, 15 from the PN group, and 11 from the TP group. No significant association was found among treatment groups and whether or not they registered for the seminar, $\chi^{2}(1, \mathrm{n}=3174)=1.35, \mathrm{p}=.51$.

Of the 35 registered participants, 31 attended. Twelve of these attendees were TP, 13 were PN's, and seven were IO's. The probability attending the seminar was $23.6 \%$ for PNs, $21.8 \%$ for TP, $12.7 \%$ for IOs. There was no significance between treatment group and attending the seminar, $\chi^{2}(1, \mathrm{n}=3174)=1.58, \mathrm{p}=.45$. Overall, from all 3174 of the invited woodland owners, attendance rates were $0.69 \%$ for the IO group, $1.2 \%$ for PNs, and $1.1 \%$ for TPs.

Newcomers (NC1) are participants who attended the first seminar, but who received zero direct mail contact from this study. There were potentially three ways these participants heard about the seminar: through friends or county extension agent, at a Society of American Foresters meeting, and from the newspaper (as the seminar details were posted in the local newspaper unbeknownst to the research team). Twenty-three NC1s attended the first seminar (figure 11). 


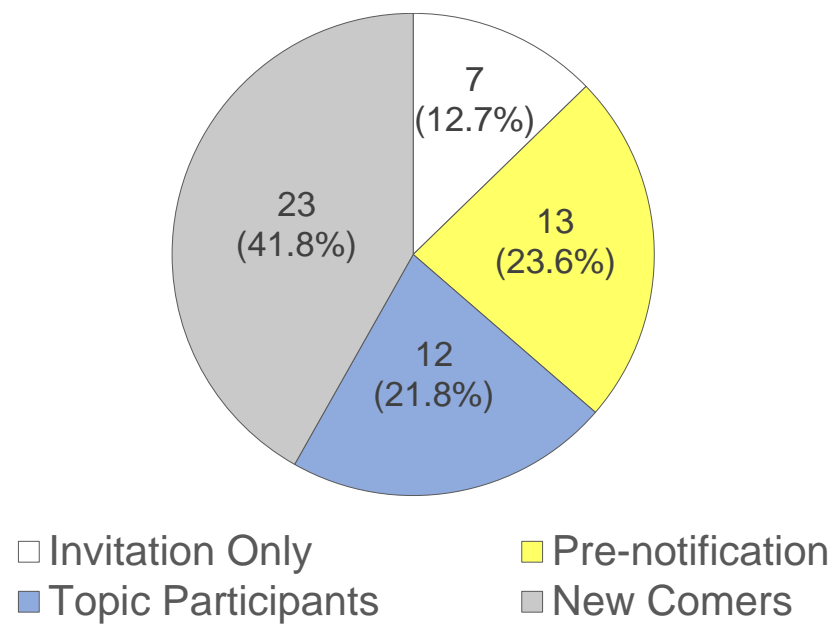

Figure 11. Pie chart illustrating number and percent of participants attending the first seminar

Of the $23 \mathrm{NC1}$ 's, 16 attended with a direct mail participant, therefore, they were assigned to those associated treatment groups. This resulted in a total of 48 attendees in the first seminar, 19 in TP, 20 in PN and 9 in IO, leaving out the seven remaining NC1's. There was no significant association between treatment and attendance after the NC1's were assigned into their respective treatment groups (Table 3; Figure 12).

Table 3. Logistic regression analysis of treatment group on registration and attendance of first seminar. Significant odds ratio $>1$ suggests higher likelihood of behavior compared with the Invitation Only (IO) reference group. Newcomers are seminar participants who attended with a study participant.

\begin{tabular}{|c|c|c|c|c|c|c|}
\hline \multirow[b]{2}{*}{ Likelihood of... } & \multirow[b]{2}{*}{ Comparison } & \multicolumn{4}{|c|}{$90 \%$ Conf. Interval } & \multirow[b]{2}{*}{$\begin{array}{l}\mathrm{p}- \\
\text { value }\end{array}$} \\
\hline & & $\begin{array}{l}\text { Odds } \\
\text { Ratio }\end{array}$ & Lower & Upper & $\begin{array}{l}\text { Chi- } \\
\text { sq }\end{array}$ & \\
\hline \multirow{4}{*}{...registering for seminar } & & ---Not & uding ne & vcomers & $----\cdot-$ & \multirow[b]{2}{*}{0.256} \\
\hline & & 1.59 & 0.792 & 3.200 & 1.29 & \\
\hline & PN vs IO & & & & & \\
\hline & TP vs IO & 1.16 & 0.550 & 2.435 & 0.05 & 0.816 \\
\hline \multirow[t]{2}{*}{...attending a seminar } & PN vs IO & 0.56 & 0.259 & 1.223 & 0.80 & \multirow{2}{*}{$\begin{array}{l}0.370 \\
0.590\end{array}$} \\
\hline & TP vs IO & 0.61 & 0.279 & 1.347 & 0.29 & \\
\hline \multirow{3}{*}{...attending a seminar } & & $-----I n$ & ling new & omers-- & ------ & \multirow{3}{*}{$\begin{array}{l}0.183 \\
0.307\end{array}$} \\
\hline & PN vs IO & 2.12 & 1.089 & 4.120 & 1.78 & \\
\hline & TP vs IO & 1.99 & 1.020 & 3.898 & 1.05 & \\
\hline
\end{tabular}




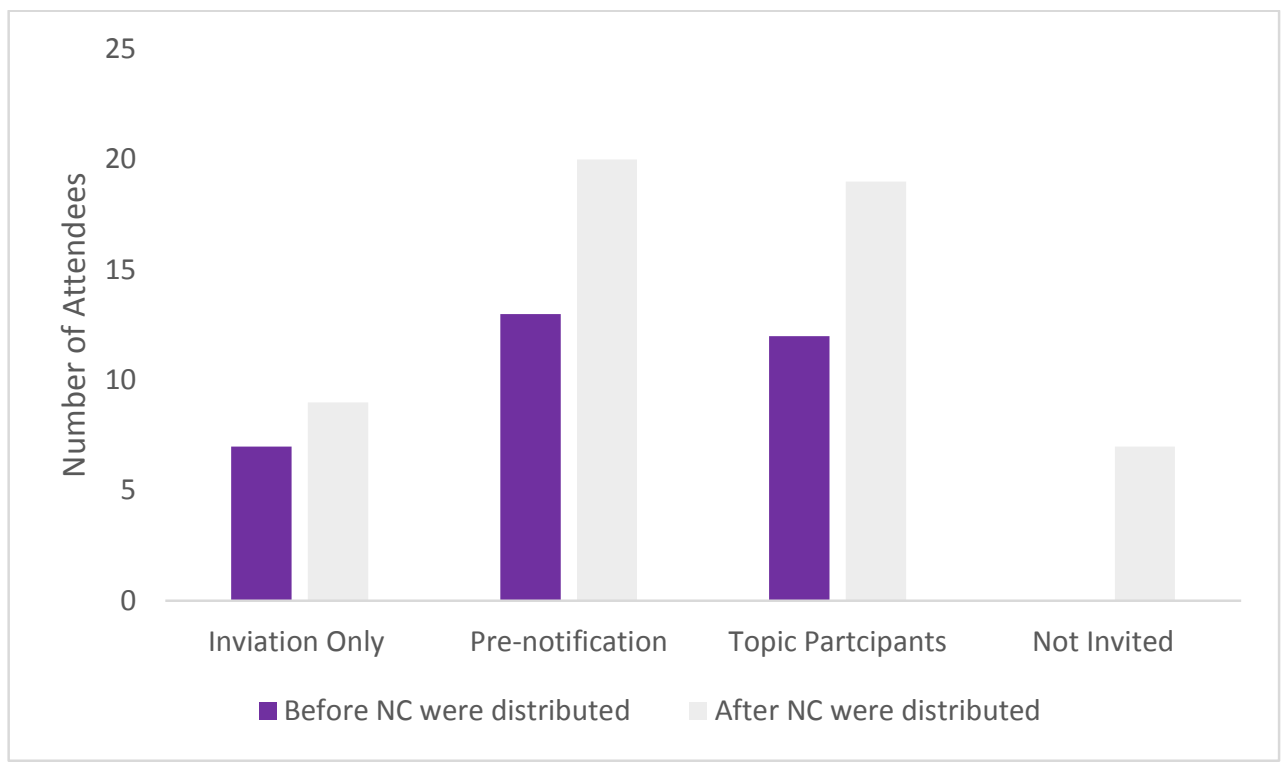

Figure 12. Comparison of attendance of first seminar prior to New Comers being assigned with their linked treatment group $(n=23)$. 


\section{Evaluation of the full series}

\section{Assessment of long-term effects of topic selection on participant attendance}

In total, there were 110 attendees for the three-part education series (Table 4). There were 55 participants in the first seminar, 21 in the second, and 34 in the third seminar. For the first seminar all 55 were unique. Unique are participants who only attended one seminar, they are a new attendee to the series. Of the 21 attendees in the second seminar 12 were unique (meaning they did not come to first seminar) and of the 34 attendees in the third seminar 22 were unique (meaning they did not come to first or second seminar), therefore there were a total of 89 unique participants in attendance (Table 5). There were 15 'repeat customers' (attended more than one seminar) of the 89 attendees. This is a $16.8 \%$ repeat customer rate. Of the 15 repeat customers, there were six PN's, four TPs, five NC's and zero IO's. There were 40 attendees who only attended seminar one, eight of these were TP, seven PN, seven IO and 18 NC. There were six who attended all three seminars, consisting of two PN, two TP, and two NC. There were 12 participants who attended only seminar two, consisting of four IO's, five PNs, two TPs and one NC2 (new comer to seminar 2). There were 22 who only attended seminar three, three TP, five PN, two IO and 12 NC3 (new comer to seminar 3) (see Figure 13). There were three attendees who attended both seminar one and two, consisting of two PNs and one NC. There were six attendees at both seminar one and three, two of each TP, PN and NC. There were zero attendees who attended both second and third seminar (see Table 4 figure 13.).

Table 4. Number of seminar attendees by group. NC represents newcomers along with associated seminar number.

\begin{tabular}{lcccc}
\hline Attendee group & Seminar 1 & Seminar 2 & Seminar 3 & Total \\
\hline TP & 12 & 4 & 7 & 23 \\
PN & 13 & 9 & 9 & 31 \\
IO & 7 & 4 & 2 & 13 \\
NC1 & 23 & 3 & 4 & 30 \\
NC2 & -- & 1 & 0 & 1 \\
NC3 & -- & -- & 12 & 12 \\
Total & 55 & 21 & 34 & 110 \\
\hline
\end{tabular}


Table 5. Total unique participants who attended only one seminar and the unique participants who attended two or more seminars. This is per treatment and the new comers.

\begin{tabular}{|c|c|c|c|}
\hline Group & $\begin{array}{l}\text { Attended one } \\
\text { seminar }\end{array}$ & $\begin{array}{c}\text { Attended two } \\
\text { or more } \\
\text { seminars } \\
\end{array}$ & $\begin{array}{l}\text { Total unique } \\
\text { participants }\end{array}$ \\
\hline Information only & 13 & 0 & 13 \\
\hline Topic participants & 13 & 4 & 17 \\
\hline Participant notification & 17 & 6 & 23 \\
\hline Newcomers1 & 18 & 5 & 23 \\
\hline Newcomers2 & 1 & 0 & 1 \\
\hline Newcomers3 & 12 & 0 & 12 \\
\hline Total & 74 & 15 & 89 \\
\hline
\end{tabular}

In the contingency analysis of treatment by attendance, controlling for county and seminar (as a repeat measure), treatment effects were significant at the alpha $=0.10$ level $\left(\right.$ Cochran-Mantel-Haenszel Statistic $\left.\chi^{2}{ }_{\text {MH }}(2, \mathrm{n}=9522)=5.61, \mathrm{p}=.06\right)$. This statistical difference results primarily from the differences between the PNs and the IOs. PNs had just over twice the odds of having more attendees represented at the three seminars than did the IOs $(\mathrm{OR}=$ $2.12,90 \% \mathrm{CI}=1.25-3.61 \mathrm{p}=0.034)$ (Table 6). Attendees from the TP group were not statistically different from the IO group $\left(\chi^{2}=(1, \mathrm{n}=9583)=0.07, \mathrm{p}=.79\right)$.

When NC1s were added to their respective treatment groups, the results were very similar although the statistical significance decreased slightly (Cochran-Mantel-Haenszel Statistic $\chi^{2} \mathrm{MH}$ $(2, \mathrm{n}=9583)=6.41, \mathrm{p}=.064)$. PNs were again twice as likely as IOs to have the greater numbers at the seminar $(\mathrm{OR}=1.95,90 \% \mathrm{CI}=1.25-3.02)$ and there were no statistical differences between TPs and IOs $\left(\chi^{2}=(1, n=9583)=0.69, \mathrm{p}=.41\right)$. 
Table 6. Logistic regression analysis of treatment group on likelihood of attending a seminar over the three consecutive seminars. Significant odds ratio $>1$ suggests higher likelihood of attending compared with the Invitation Only (IO) reference group. Newcomers are seminar participants who attended with a study participant.

\begin{tabular}{|c|c|c|c|c|c|}
\hline \multirow[b]{2}{*}{$\begin{array}{l}\text { Groups attending } \\
\text { seminars }\end{array}$} & \multicolumn{3}{|c|}{$\begin{array}{l}90 \% \text { Confidence } \\
\text { interval }\end{array}$} & \multirow[b]{2}{*}{ Chi sq } & \multirow[b]{2}{*}{$\begin{array}{l}\mathrm{p}- \\
\text { value }\end{array}$} \\
\hline & $\begin{array}{l}\text { Odds } \\
\text { Ratio }\end{array}$ & Lower & Upper & & \\
\hline \multicolumn{6}{|l|}{ Not including newcomers } \\
\hline PN vs IO & 2.12 & 1.245 & 3.606 & 4.52 & 0.034 \\
\hline TP vs IO & 1.56 & 0.893 & 2.734 & 0.07 & 0.789 \\
\hline \multicolumn{6}{|l|}{ Including newcomers } \\
\hline $\mathrm{PN}$ vs IO & 1.95 & 1.254 & 3.026 & 3.98 & 0.046 \\
\hline TP vs IO & 1.67 & 1.060 & 2.618 & 0.69 & 0.406 \\
\hline
\end{tabular}

\section{Attendance associations between seminars of woodland owners who indicated interest in attending $(n=41)$}

Among the 41 TPs who indicated interest in attending the three-part series, there was a weak indication of a significant association between attending the first and second seminar (Fisher's exact test $\mathrm{p}=0.0919$ ). As $25 \%$ of those who attended the first seminar also attended the second seminar, while only $3 \%$ of the TPs who did not attend the first seminar, attended the second seminar. Using a slightly different measure, a ratio of these proportions (relative risk, RR; 0.25/0.03), the conditional probability of a person attending the second seminar given they attended the first is 8.25 times higher than for those who did not attend the first $(\mathrm{RR}=8.25$, CI 0.85-50.07). The large confidence interval limits indicate a low precision of the measure due to the overall low number of participants (Figure 13). 


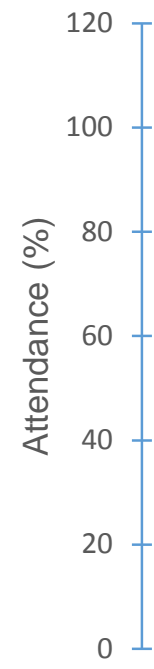

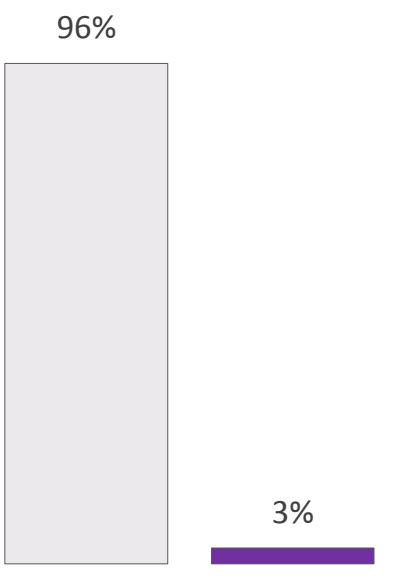

Did Not Attend Seminar 1 $\square$ Did not attend Seminar 2

- Attended Seminar 2

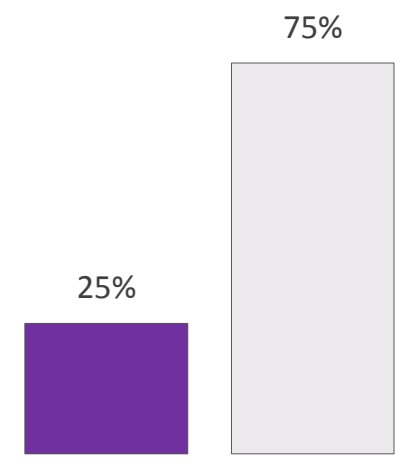

Did Attend Seminar 1

Figure 13. Association between attending seminar one and attending seminar two, of those that expressed interest at onset of seminar series $(n=41)$.

Among the 41 TPs who indicated interest in attending the three-part series, there was found to be a weak significant association of attendance between the first and third seminar (Chisquare $\mathrm{p}$-value $=0.0003$ ), as $50 \%$ of those who attended the first seminar, also attended the third seminar while only $3 \%$ of those who did not attend seminar one attended seminar three. The conditional probability of a person attending the third seminar given they attended the first seminar is 16.5 times higher than for those who did not attend the first seminar (Relative risk=16.5, CI 2.83-361.79). This large confidence interval limits indicate a low precision of the measure due to the overall low number of participants. (Figure 14). 


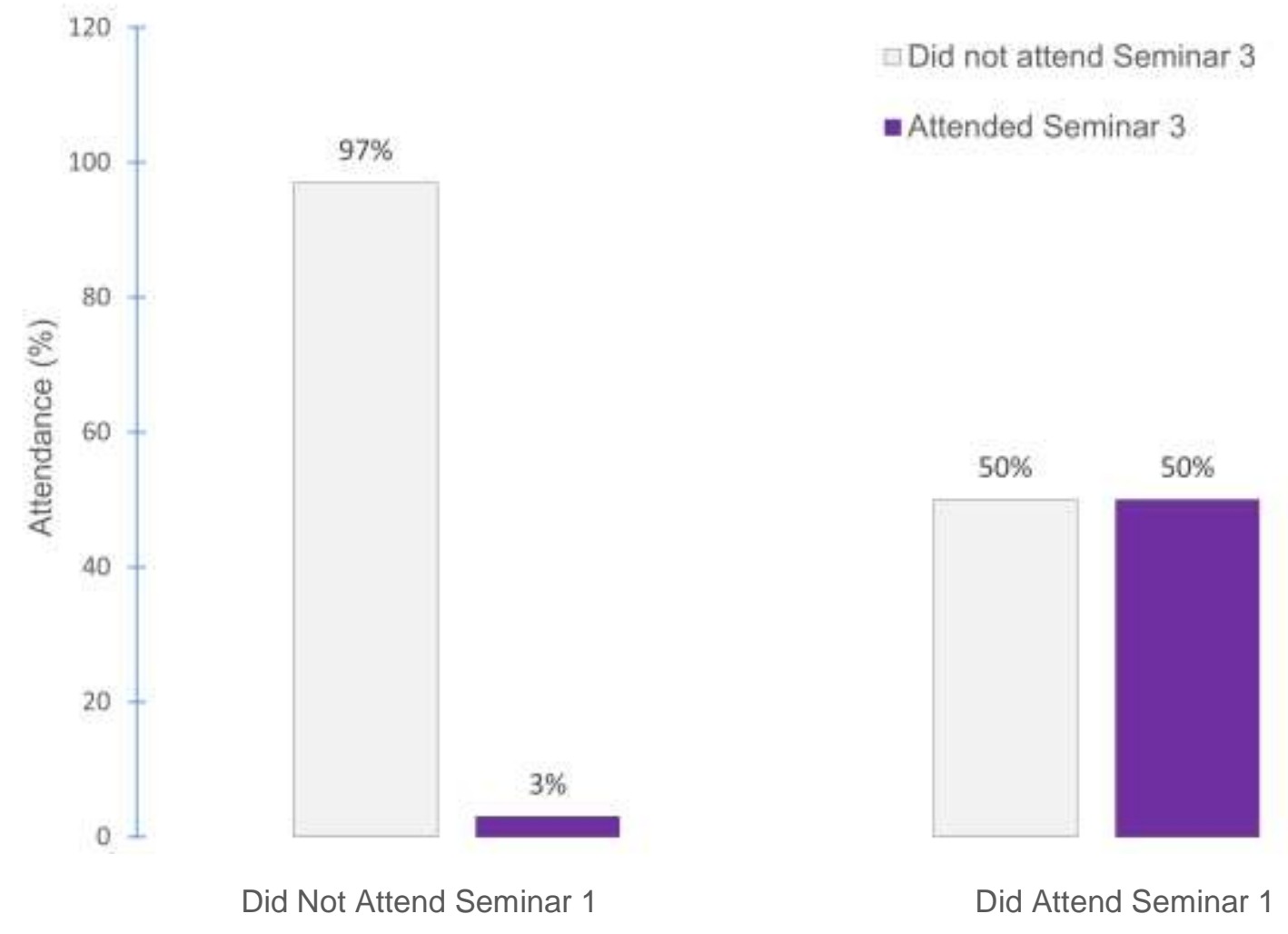

Figure 14. Association between attending seminar one and attending seminar three, of those that expressed interest at onset of seminar series $(n=41)$.

Among the 41 TPs who initially indicated interest in attending the three-part series, there was a weak significant association of attendance between the second and third seminar (Chisquare $\mathrm{p}$-value $=0.0347)$. As $66 \%$ who attended the second seminar also attended the third seminar, while only $8 \%$ of the TPs who did not attended the second seminar, attended the third seminar. The conditional probability of a person attending the third seminar given they attended the second is 23.33 times higher than those who did not attend the first (Relative risk=8.44, CI 2.19-32.53). The large confidence interval limits indicate a low precision of the measure due to the overall low number of participants (Figure 15). 


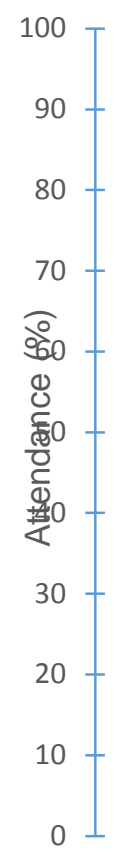

$92 \%$

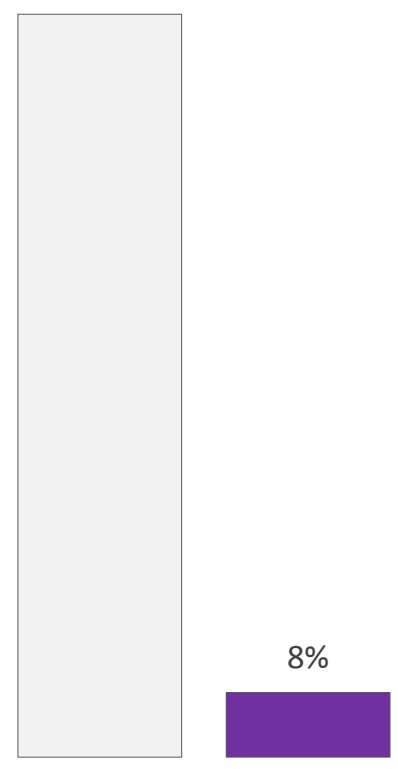

Did Not Attend Seminar 2 $\square$ Did not attend Seminar 3 attended Seminar 3

$66 \%$

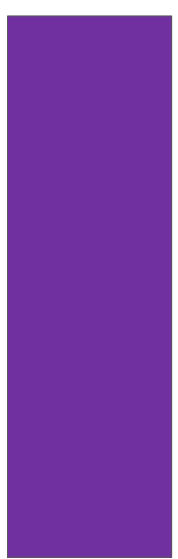

Did Attend Seminar 2

Figure 15. Association between attending seminar two and attending seminar three, of those that expressed interest at onset of seminar series $(n=41)$. 


\section{Chapter 5: Discussion}

The Season's in the Woods study supports the work of Zobrist \& Rozance, (2015) indicating a low correlation between expressed educational needs and seminar participation as there was found to be no significant association between a participant attending even when their topic of interest was selected. Zobrist \& Rozance (2015) found that after six years of offering highly ranked topics, attendance was low, however when they offered workshops on the lowranked topics workshops were always well attended. One potential explanation is that low attendance may be a result of not meeting landowners preferred method of receiving the educational information. A seminar setting is not every landowner's preferred means of gaining knowledge. Zobrist and Rozance (2015) found that over half of the 2,915 surveyed Washington state woodland owners preferred to meet their educational needs via printed materials, while online was the second favored way to receive materials. For the WV woodland owner, conferences and workshops were second to least preferred means of receiving woodland focused information according to the 277 West Virginia non-industrial private woodland owners who participated in the last National Woodland owners Survey (National Woodland Owners Survey 2013). The most preferred means of receiving educational materials were through more passive means as they preferred written materials such as bulletins or newsletters, followed by talking to someone, internet, and someone visiting them on their land, while some just didn't want any information (Butler et al., 2016).

This study gave some support for Perks (2012) finding that by simply providing learners with educational options such as a short list of topics, students are motivated by a sense of control. It was challenging to make inferences about whether or not a participant felt a sense of control in our study, however, 78\% of the TP's indicated interest in attending the seminar series as compared to the $48 \%$ of PN who indicated interest. The TP group showed a greater attendance rate for seminar one $(1.11 \%)$ than the IO's $(0.69 \%)$, yet a slightly smaller but nonsignificant attendance rate than the PN group (1.21\%). This pattern was found to be similar when the NC1's were linked to the treatment group of the person they attended the seminar with. The TP probability of attending (0.345) continued to represent more attendees than the IOs 
(0.163), yet less than the PN group (0.363). This could suggest that choice motivated interest in attending, but not enough to encourage attendance.

The surprising finding was that almost half $(42 \%)$ of the attendees to seminar one were New Comers (NC1s). The NC1s were participants who attended the first seminar without receiving direct mail contact from this study. The numbers of attendees among treatment groups altered when the NC1's were assigned to the corresponding treatment group of the person they attended with, so much so that there became a significant association between treatment and seminar attendance. On the TP and PN postcards, woodland owners were asked to indicate if they would be attending the series and how many people will be attending. The IO's did not get this option. It could be that by merely asking woodland owners if they intend to attend and requesting the number of people that will be joining them is a factor in landowners bringing others. This finding corresponds to the 2008 Jones et al. study of outreach methods as there was a good representation of direct mail participants (39\%) when compared with other outreach methods. They found that of 146 workshop participant surveys, 19\% learned of the workshop via “other". They defined "other" as word of mouth or farm supply store. Apart from NC1s, the current study found that $43 \%$ of the 55 attendees learned of the seminars via other communication channels (newspaper, Society of American foresters meeting, or an invitee). This is almost double the amount of treatment group attendees. Our finding of a large percentage of New Comers was higher than a Hughes et al. (2005) study. They found that "workshop attendance was directly related to the number of landowner letters mailed" as less than $10 \%$ heard of the workshop via other means and close to $15 \%$ heard via newspaper compared to direct mail, church, radio, personal contact, radio or flyer/brochure (Hughes et al. 2005 provided an illustration as opposed to hard numbers or percentages and did not define other).

Perhaps another factor influencing woodland owners to bring others is that they were contacted twice via direct mail prior to registration. It was found in our study that those that were contacted twice prior to registration via direct mail brought the most New Comers to the seminar. This may be simply because TPs and PNs were given the chance to list how many guests they might bring, or it could have been because of the reminder mailout. Gerber \& Green, (2000) found that multiple mailing can slightly increase voter turnout. To explore effective ways to increase voter turnout they implemented a variety of treatments including direct calling, face 
to face and multiple mailings. Multiple mailing was found to have a slight impact on voter turnout as it increased by 2.5 percentage points (based on the $44.5 \%$ turnout rate of the treatment groups). By using repeated exposures to advertise our seminar we essentially applied the twofactor theory (Anand \& Sternthal, 1990). It could be possible that the landowners who brought someone had an increased level of trust regarding the seminar and experienced the positive habituation factor. If so, does that mean those that did not respond or attend became bored (due to a heightened tedium factor) with the direct mailing of the two postcards and that the trust with the host agency was lowered? This question remains speculative and its answer would have to be researched in future investigations.

Malmsheimer \& Germain, (2002) considered that low attendance may be due to providing education seminars too long after the landowner needs assessment was completed, They found seminar attendance for top ranked topics in a needs assessment completed two years prior to seminar delivery were poorly attended. The seminars offered through Seasons in the Woods attempted to minimize time between needs assessment and seminar as there were 56 days between mail out of the initial topic selection postcard and the final reminder and IO invitation mail out.

In this study only 15 of the 89 unique attendees went to more than one seminar. This percentage is only half of the repeat customers that Bess \& Traub (2013) found during their 12 and eight-week seminar series. Twenty five percent of those participants were repeat customers. In the Seasons in the Woods study $16.8 \%$ were repeat customers. In contrast to the Bess \& Traub (2013) study, Seasons in the Woods was three seminars within one year, not on a weekly basis. Perhaps the repeat customers would increase if our seminars were closer together in time and across a longer stretch of time perhaps.

\section{Limitations}

Potential weakness within this study include, number of woodland owners in the study, time of year direct mail outreach began and possible postal issues.

The number of people who actually came to the seminars was much smaller than the initial mail out thus affecting the statistical significance of the findings. To determine the size of our sample for this study we referred to the Krejcie and Morgan, 1970 paper "Determining 
Sample size for research activities". This paper suggested that a sample size between 341 and 351 which would provide strong confidence in the statistics. Our original mail out number was 3600 , this was lowered, due to bad address and death, to a total of 2154 . This remained well above the suggested sample size given by Krejcie and Morgan. Our sample size radically decreased as the numbers of response postcards, registrants and attendees were very low. The sample size was too small to make significant conclusions between topic selection and expressing interest in, registering plus attending the seminar series. When statistics are used on a small number of observations they tend to have a larger variance than if there were more observations. So the marginally significant findings would likely be more significant if we had used an even larger number of invitations.

Another limitation could have been the timing. This project began in the spring of 2015 . Beginning the project in one of the other seasons might have affected the mail response and attendance. Further research would be needed to find what time of year woodland owners most respond, register and attended seminars.

The addresses used to mail out the three treatments were based off the 2013 tax roll. As landownership and fragmentation of the land continually occurs this may not have been the most current list of woodland landowners in West Virginia. Another addressing limitation may have been the potential interruption in the U.S. postal service. The West Virginia mailing addresses were updated to reflect the new 9-1-1 addressing system. Updating for this was slow and inconsistent throughout the state. We were not aware of this change before mailing took place.

\section{Conclusion, Recommendations, and Future Work}

Private non-industrial woodland owners play an important role in maintaining the health of West Virginia's woodlands, as they collectively make up 60\% ownership of the 12 million acres of the states forested land. Studying how direct mail affects woodland owner attendance to woodland focused seminars can assist natural resource educators to direct their outreach efforts. By improving these efforts more woodland owners can be reached, consequently leading to more private non-industrial woodland owners being better informed and equipped to reach their land management objectives. This study was a good spring board to exploring outreach methods. 
Being open to providing woodland owners with the educational topics they want and in a time frame that is quick may involve using all forms of educational outreach such as newspapers, bulletins, radio, and direct mail. As mentioned earlier, one factor that could have influenced newcomer attendance is encouraging landowners to bring a friend, as the TP and PN invitation to the three part series had a line specifically asking how many people they plan to bring. This simple question could be built into future advertising and networking efforts in order to reach more participants and encourage attendance.

Natural resource educators must also consider offering preferred topics in a fashion that is suited to the landowner. This may involve creating more than just one presentation, it may involve creating written materials and posting those materials in bulletins, newsletters and the internet to ensure woodland owners are able access the information they are seeking in their preferred method.

A suggestion for future direct mail outreach is to focus on fewer, more deliberately targeted woodland owners landowners. This could be done by reviewing and categorizing landowners using the National woodland owner survey or adopting the attitudinal segmentation of woodland owners described my Butler et al. (2017). Another way to target landowners may be to utilize GIS to overlay tax roll addresses on the county parcel to find areas with high concentrations of landowners or high risk areas such as riparian zones, high debris area or places of high erosion. By understanding high risk areas, educator can develop an outreach campaign targeting landowners in the areas that require unique management strategies.

If I were to do this study again, I would ensure the tax roll is as current as the budget can allow. I would contact the U.S. postal service to ensure there would be no interruptions in service such as the 9-1-1 updating in West Virginia. The postcards would have a few more details such as exact location where the seminar would be held. On every piece/point of contact it is recommended that landowners are encouraged to bring someone. Additionally, workshop developers should emphasize that the seminar is for all non-industrial private woodland land owners of 10 acres or greater regardless of management objectives or current management involvement. For example, I was asked by a registering woodland landowner over the phone from Hampshire County, "I have 12 acres, is this big enough?" 
There are many reasons why many survey respondents may not have attended our workshops. Some relate to circumstances beyond educators' control, such as family obligations, or illness. Other reasons may relate to the workshops themselves. A further look at the evaluations may reveal some of this as well as an evaluation of the reasons a woodland owner did not attended a seminar via direct mail and emailed survey or a focus group. 


\section{Literature cited}

Anand, P., Sternthal, B. 1990. Ease of message processing as a moderator of repetition effect in advertising. Journal of marketing research.

Andrejczyk K., Butler B.J., Tyrrell, M.L, Langer J. 2016 Hansel and Gretel Walk in the Forest, Landowners Walk in the Woods: A Qualitative Examination of the Language Used by Family Forest Owners Journal of Forestry

Ballantine. 2015. How to boost your direct mail marketing response rates. Retrieved from https://www.ballantine.com/ultimate-guide-boosting-direct-mail-response-rate/ on September $30^{\text {th }} 2016$.

Bess, M.M., Traub, S.M. 2013. Repeat Customer Success in Extension. Journal of Extension.

Billingham, J. 2014. Five reasons to include community decision making. Thought exchange. Retrieved from https://thoughtexchange.com/5-reasons-to-include-community-in-decisionmaking/ on December $15^{\text {th }} 2015$.

Blinn, C.R., Jakes, P.J., Sakai, M. 2007. Forest Landowners Cooperatives in the United States: A Local focus for Engaging Landowners. Journal of Forestry. VO1.105. No.5.

Burkhart-Kriesel, C, Caine, B. 2004.From potluck suppers to on-line seminars: The evolving "face" of Social Interactions. Journal of Extension.

Butler, B.J., Leatherberry, E.C. 2004. America’s Forest Owners. Journal of Forestry.

Butler, B.J., Tyrrell M, Feinberg, G., VanManen, S., Wiseman, L., Wallinger S. 2007.

Understanding and Reaching Family Forester Owners: Lessons from Social Marketing Research.

Butler, B.J., Tyrrell M, Feinberg, G., VanManen, S., Wiseman, L., Wallinger S. 2007.

Butler, Brett J. 2008. Family Forest Owners of the United States, 2006. Gen. Tech. Rep. NRS27. Newtown Square, PA: U.S. Department of Agriculture, Forest Service, Northern Research Station. 72 p. 
Caffarella R. S., Daffron S.R. 2013. Planning Programs for Adult Learners. A Practical Guide. $3^{\text {rd }}$ Edition. Jossey-Bass. United States.

Caffarella Rosemary S. 1982. Identifying Client's Needs. Journal of Extension, vol.20

Campbell L.G., McGill D.W., Pierskalla C. 2007. The Role of the West Virginia Extension Service in Forestry Education and Technical Assistance Journal of Extension. Vol. 45 Number 6

Childs R.A. 2005. West Virginia's Forests Growing West Virginia’s Future http://www.wvforestry.com/Economic\%20Impact\%20Study.pdf retrieved on December $5^{\text {th }} 2016$.

Clarkson-Frisbie J., Bartman, D., Gregov, C., Gregory E., Hoelscher Day, S. 2008. Living well: National Extension association of Family and Consumer Sciences National Media Campaign. Journal of Extension. Vol. 46. Num.6

Cornelius-White J. 2007. Learner-Centered Teacher-Student Relationships are Effective: A Meta-Analysis. Review of Educational Research Vol77. No.1

County of Greenbrier (2017, January) 2017 Addressing and Mapping; County of Greenbrier West Virginia. http://www.greenbriercountyhsem.org/addressing-and-mapping.html

Danks, C 2008. Institutional arrangements in community based forestry" In forest Community connections: Implications for research, management and governance, edited by E. Donoghue and V. Sturtevant. Washington DC: Resource for the future.

Deci E.L. The Relation of Interest to the Motivation of Behavior: a Self-Determination Theory Perspective. An essay/chapter from the book Renninger K.A., Hidi S., Krapp A. 1992. The role of interest in learning and development. New York, U.S.A.

Downing, A.K, Finley, J.C, 2005.Private Forest Landowners: What They Want in an Educational Program. Journal of Extension. Vol.43. Number 1

Dunn M.A, Glenn H., Grado S.H., Idassi J.O., Measells M.K., Zielinske R.J. 2006 Educational Needs of Southern Forest Landowners. Journal of Extension. Vol. 44 Number 5 
Evans, M., Patterson, M., O’Malley L. 2001. The direct marketing-direct consumer gap: qualitative insights. Qualitative Market Research: An International Journal. Vol4. Iss.1

Fegel, T., (2014) Comparing educational preferences and management roles of West Virginia's Male and Female Woodland owners. (Unpublished master's thesis). West Virginia University, Morgantown West Virginia.

Ferrari, T.M., Turner C.L., 2006. An Exploratory Study of Adolescents' motivation for joining and continued participation in a 4-H afterschool program.

Gerber, A.S., Green, D.P. 2000. The Effects of Canvassing, Telephone Calls, and Direct Mail on Voter Turnout: A Field Experiment Source. The American Political Science Review, Vol. 94, No. 3

Germain R.H., Malmsheimer R.W. 2002. Needs Assessment Surveys: Do They Predict Attendance at Continuing Education Workshops? Journal of Extension. Vol20.Num.4

Goote, R.S., Blanter, K.A., Baumgartner D.M., Carroll, M.S., Weber, E.P. 2010. Choosing what to believe about foresters: Differences between Professional and non-professional evaluative criteria. Small-scale forestry.

Hidi S., Krapp A. Renninger K.A. 1992. The Role of Interest in Learning and Development. The American Journal of Psychology

Hock, S., Anderson, S., Potoski, M. 2012. Invitation Phone Calls Increase Attendance at Civic Meetings: Evidence from a Field Experiment. Public Administration Review, Vol. 73 Iss.2.

Hughes G., Measells, M.K., Grado S.C., Dunn, M.A., Idassi J.O., Zielinske R.J. 2005. Underserved Forest Landowners Workshops: Opportunities for Landowners and Extension. Journal of Extension. Vol. 43 Num. 4

Iyengar S.S., Lepper M.R. 2000. When Choice is Demotivating: Can One Desire Too Much of a Good Thing? Journal of Personality and Social Psychology, Vol. 79, No. 6.

Jackson B. 2016. Recent E-911 address change causing frustration for W.Vs flood victims seeking FEMA help. WSLS10 News Bureau. Retrieved on January $21^{\text {st }} 2017$ at 
http://wsls.com/2016/07/05/recent-e-911-address-changes-causing-frustration-for-w-va-floodvictims-seeking-fema-help/

Jones W.D, Jacobs, K.M., Yarrow, G.K., McPeake, R. 2008. Using Workshops to Educate Landowners about Developing Natural Resources Enterprises to Diversify Income on the Family Farm. Journal of Extension. Vol.46 Issue 5.

Khanal, P.N., Grebner, D.L., Munn, I.A., Gardo, S.C., Grala R.K., Henderson J.E. Typology of Nonindustrial Private Forests Landowners and Forestry Behavior: Implications for Forest Carbon Sequestration in the Southern US.

Krejcie, R.V., Morgan, D.W. 1970. Determining Sample Size for Research Activities. Education and Psychological Measurements. Vol.30, 3:pp.607-610.

Kuhns M., Burnson M.W., Roberts S.D. 1998. Landowners’ Educational Needs and How Foresters Can Respond. Journal of Forestry. Vol.96 Issue 8

Kuipers B.T., Shivan G.C., Potter-Witter K. 2013. Identifying Appropriate Communication Means for reaching Nonindustrial Private Forest Landowners. Journal of Forestry.

Kvale, S. Brinkmann S. 2009. Interviews: Learning the Craft of Qualitative Research Interviewing. Sage, CA.

Lee Hea-Jin. 2005. Developing a Professional Development Program Model Based on Teachers' Needs. The Professional Educator. Vol.27. Num. 2

Lockard. M., Petty B., Peutz J., Spencer, M., Lanting, R., Shaklee H. 2010. Working Smart: Increasing the Reach to Extension Programming Through Media Advertising. Journal of Extension. Vol. 48 num. 1

Longo, A.J., Kushla J.D., Smallidge, P. 2008. Use of County Tax Roll for the Creation of Mailing lists for Extension Programming. Journal of Extension. Vol. 46 Num.6

McCuen M., McGill D., Arano K., Owen S. 2013. West Virginia Woodland Welcome Wagon: Design, Implementation and Evaluation in Three Priority Areas. Journal of Extension. Vol. 51. Num 4 
McMillan, D.W., Chavis D.M. 1986. Sense of Community: A Definition and Theory Journal of Community Psychology Volume 14

McPherson M., Smith-Lovin L., Cook J. 2001. Birds of a Feather: Homophily in Social Networks. Annual Review of Sociology. Vol. 27:415-444.

Measells M.K, Grado S.C, Hughes H.G, Dunn M.A, Idassi J.O, Zielinske R.J. 2006. The educational need of Southern Forest Landowners. Journal of Extension. Vol.44 num. 5

Morgan D.W., Krejcie R.V. 1970. Determining Sample Size for Research Activities. Educational and Psychological Measurement

Morimoto, M., Chang, S. 2006. Consumers' attitudes toward unsolicited commercial e-mail and postal direct mail marketing methods: Intrusiveness, perceived loss of control and irritation. Journal of Interactive Advertising.vol.7, Issue 1.

National Woodland Owner Survey. 2013. Retrieved on November 9th 2016 from http://www.fs.fed.us/nrs/pubs/rb/rb_nrs99.pdf

Nehiley, J.M. 2001. Developing a Simple Four-Step Marketing Plan for Extension Programs. Journal of Extension. Vol. 39, Num2.

O'Neill Barbara M. Gaining "Repeat Customers” for Extension. Journal of Extension, 1993. vol. 31 , Issue 2

Parker, S., Powell L., Hermann, J., Phelps J., Brown, B. 2011.Preferred Education Delivery Strategies Among Limited Income Older Adults Enrolled in Community Nutrition Education Programs. Journal of Extension. (Parker et al. 2011)

Perks, K. 2010. Crafting Effective Choices to Motivate Students. Adolescent Literacy in Perspective; Student Choice and Engagement.

Petersen C. 2006 Report to NEFA on Landowner Education Initiatives: How to effectively deliver forest stewardship information and knowledge to private forestland owners in the NEFA region. Retrieved on November $7^{\text {th }} 2016$ from http://www.nefainfo.org/ 
Porras-Hernandez L. Salinas-Amescua B. 2012. Nonparticipation in Adult Education: From SelfPerception to Alternative Explanations. Adult Education Quarterly. Vol. 62(4)

Renninger, K.A, Hidi S, Krapp A. 1992.The Role of Interests in Learning and Development.

Roberson Jr. D., Merriam S. 2005. The Self-Directed Learning Process of Older, Rural Adults. Adult Education Quarterly. Vol. 55(4)

Salmon, O., Brunson, M., Kuhns M. 2006. Benefit-Based Audience Segmentation: A tool for Identifying Nonindustrial Private Forest (NIPF) owner education needs. Journal of Forestry.

Scherr S.J., Shames, S., Friedman, R. 2013. Integrated Landscape Management for Policy Makers EcoAgriculture Partners. Retrieved from (http://www.un.org/esa/ffd/wpcontent/uploads/sites/2/2015/10/IntegratedLandscapeManagementforPolicymakers_Brief_Final_ Oct24_2013_smallfile.pdf) on March $1^{\text {st }} 2016$.

Schrock D.S., Meyer, M., Ascher, P., Snyder, M. 2000. Benefits and Value of the Master Gardener Program. Journal of Extension. Vol. 38

Smathers, P., Camp, D., Hampson, D., Alcock B., Ison, J., Stephens, L. 2010. Choice at Finland Middle School. Adolescent Literacy in Perspective; Student Choice and Engagement.

Starr S.E., McConnell T.E., Bruskotter J.S., Williams R.A. 2014 Typology of Ohio, USA, Tree Farmers Based upon Forestry Outreach Needs. Environmental Management.

Tidwell-Howell J. 2010. Providing Choice-A risk Work taking for teachers and students. Adolescent Literacy in Perspective; Student Choice and Engagement.

Tools for engaging woodland owner's effectively. 2016. Woodland owner Survey. Retrieved on December 5, 2016 from http://www.engaginglandowners.org/sites/default/files/documents/profiles/TELE_OBJ_LEGAC Y_WEST_VIRGINIA.pdf

Torell, R., Bruce, B., Kvasnicka, B.1999. Promoting and Organizing Agricultural Extension Meetings. Journal of Extension. Vol. 37. Num1 
Umaerus P., Lidestav G., Eriksson L.O., Nordin M. H. 2013. Gendered business activities in family farm forestry: From round wood delivery to health service. Journal of Forest Research

Vanderford E. Gordon J.S., Londo A.J., Munn I.A. Using focus groups to assess educational programming needs in forestry. 2014. Journal of Extension. Vol 52

Velassery S. 2012. Globalization and Cultural Identities: Philosophical Challenges and Opportunities. New Delhi. Overseas Press. Pp. 119-126

Walter V. Reid, Harold A. Mooney, Angela Cropper, Doris Capistrano, Stephen R. Carpenter, Kanchan Chopra, Partha Dasgupta, Thomas Dietz, Anantha Kumar Duraiappah, Rashid Hassan, Roger Kasperson, Rik Leemans, Robert M. May, Tony (A.J.) McMichael, Prabhu Pingali, Cristián Samper, Robert Scholes, Robert T. Watson, A.H. Zakri, Zhao Shidong, Neville J. Ash, Elena Bennett, Pushpam Kumar, Marcus J. Lee, Ciara Raudsepp-Hearne, Henk Simons, Jillian Thonell, and Monika Zurek B. Ecosystem and human well-being synthesis. Millennium ecosystem assessment. 2005. Retrieved on December $5^{\text {th }} 2016$ at http://www.millenniumassessment.org/documents/document.356.aspx.pdf

West Virginia Extension Vision Statement. Retrieved on November 9th 2016 from https://ext.wvu.edu/about_extension/overview.

Widmann, R.H., Cook, G.W., Barnett, C.J.,Butler B.J., Griffith, D.M., Hatfield, M.A., Kurtz, C.M., Morin R.S., Moser, W.K., Perry, C.H, Piva, R.J., Riemann, R., Woodall, C.W. West Virginia's Forests 2008. 2008. U.S Forest Service.

WVFA Forestry Facts retrieved on January, $23^{\text {rd }} 2017$ at http://wvfa.org/forestry-facts/

Zobrist K.W., Rozance M.A. 2015. Forest Landowner Education Interests and Delivery Preferences: A Retrospective Look at Survey Results and Actual Participation. Journal of Extension. Vol.52 Num.5 


\section{Appendix}

Table 10. Attendance by County and treatment group. The treatment group the NC, NC2 and NC3 were linked with are listed.

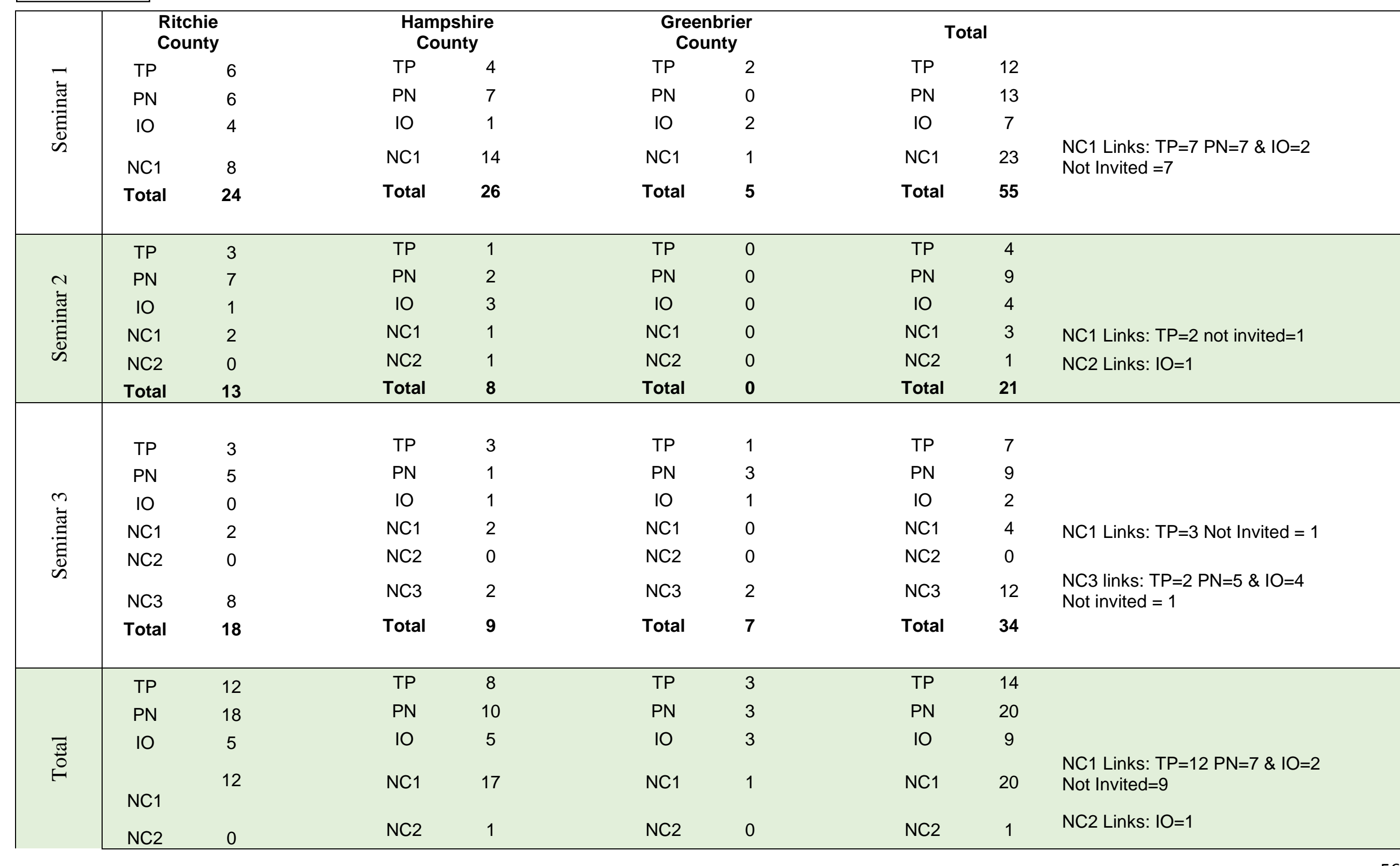




\begin{tabular}{|c|c|c|c|c|c|c|c|c|}
\hline NC3 & 8 & NC3 & 2 & NC3 & 2 & NC3 & 12 & $\begin{array}{l}\text { NC3 links: TP=2 PN=5 \& IO=4 } \\
\text { Not invited }=1\end{array}$ \\
\hline Total & 55 & Total & 43 & Total & 12 & Total & 110 & \\
\hline
\end{tabular}


